\title{
1 Challenges in Biogas Production from Anaerobic Membrane Bioreactors
}

2

\section{Cheng Chen ${ }^{\mathrm{a}}$, Wenshan Guo ${ }^{\mathrm{a}}$, Huu Hao Ngo ${ }^{\mathrm{a} *}$, Duu-Jong Lee ${ }^{\mathrm{b}}$, Kuo-Lun Tung ${ }^{\mathrm{b}}$, Pengkang} Jin $^{\mathrm{c}}$, Jie Wang ${ }^{\mathrm{d}}$, Yun $\mathrm{Wu}^{\mathrm{d}}$

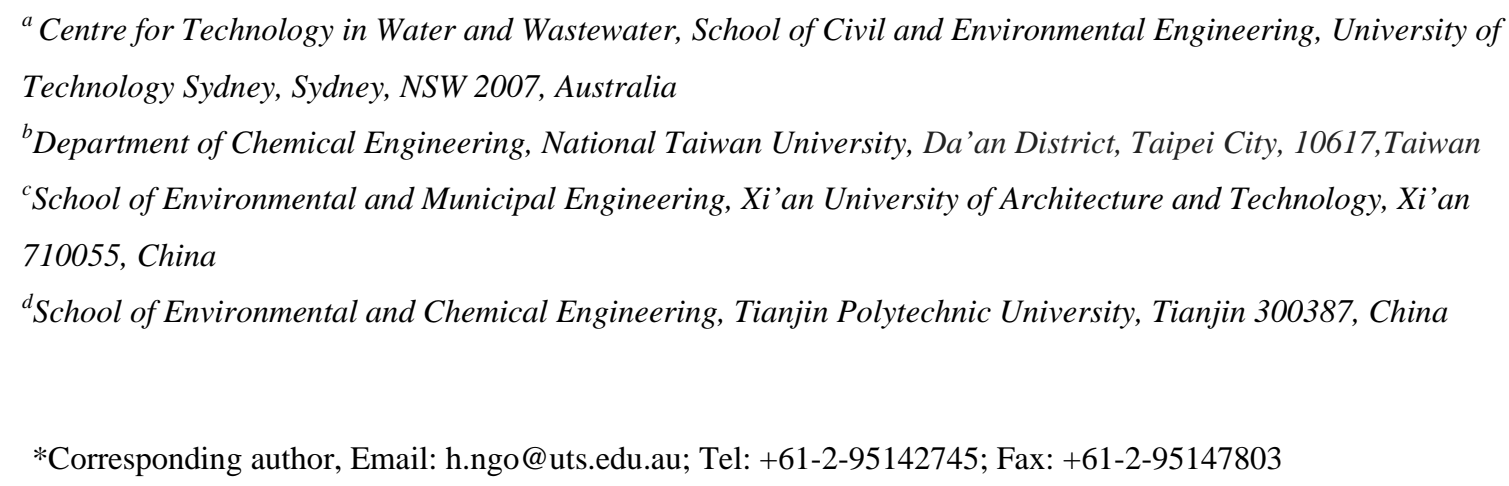

\section{Abstract}

Spectacular applications of anaerobic membrane bioreactors (AnMBRs) are emerging due to the membrane enhanced biogas production in the form of renewable bioresources. They produce similar energy derived from the world's depleting natural fossil energy sources while minimizing greenhouse gas (GHG) emissions. During the last decade, many types of AnMBRs have been developed and applied so as to make biogas technology practical and economically viable. Referring to both conventional and advanced configurations, this review presents a comprehensive summary of AnMBRs for biogas production in recent years. The potential of biogas production from AnMBRs cannot be fully exploited, since certain constraints still remain and these cause low methane yield. This paper addresses a detailed assessment on the potential challenges that AnMBRs are encountering, with a major focus on many inhibitory substances and operational dilemmas. The aim is to provide a solid platform for advances in novel AnMBRs applications for optimized biogas production. 
Keywords: anaerobic membrane bioreactor, biogas production, methane, inhibitors

\section{Background}

35

\subsection{Biogas and its sustainability}

Biogas represents one of the most highly appreciated opportunities to utilize certain categories of biomass to fulfill partially the world's energy needs. Biogas commonly refers to a mixture of gases produced by the biological breakdown of organic matter in the absence of oxygen, of which methane, hydrogen and carbon monoxide can be combusted or oxidized with oxygen. The energy output/ input can reach up to $28.8 \mathrm{MJ} / \mathrm{MJ}$ under favorable conditions, contributing to a very efficient use of the valuable biomass [1]. The resultant energy release allows biogas to be used as a biofuel to replace conventional fossil energy sources (coal, oil, natural gas) in power and heat production, and also as a versatile renewable energy source to fuel vehicles with lower sale price compared to diesel and petrol [2, 3].

In general, widespread installation and proper functioning of biogas production systems can provide many benefits to users and the wider community. Advantages include energy sustainability, resource preservation and environmental conservation. On the one hand, the long-term utilization of declining fossil fuels is considered unsustainable because of their

51 limited reservoirs and non-renewable nature. Biogas derived from various biological sources

52 can reduce the heavy dependence on these depleting natural resources, and address the energy

53 insecurity concerns due to its renewable, widely applicable, and abundant characteristics [2,

54 4]. On the other hand, the valorization of the generated biogas is that it is energy efficient (a typical value for electrical efficiency is $33 \%$ while for thermal efficiency it is $45 \%$ ) and

56 environmentally friendly due to the low emission of hazardous pollutants, for example

57 volatile organic compounds (VOCs) [5]. In terms of the current $\mathrm{CO}_{2}$-mitigation policy, biogas, 
as a nearly GHGs-neutral replacement for fossil fuels, can be produced from widely available

renewable feedstocks, and their production barely contributes to the net carbon emission [6].

Optimistically, the rapid development of biogas production not only can reduce the world's heavy reliance on fossil fuel and thereby global energy needs, but also reduce the carbon footprint from fossil fuel utilization. This means decelerating the drift to global warming and climate change.

64 biomass from various sources (animal waste, domestic sewage, industrial wastewater, agricultural waste, etc.). The anaerobic digestion of complex organic matter to biogas (mainly methane and carbon dioxide) involves four key steps, these being hydrolysis, acidogenesis, acetogenesis and methanogenesis (see Fig. 1.). A balanced methane fermentation process requires individual degradation phases to be carried out by distinct consortia of bacteria, namely fermentative bacteria, syntrophic acetogens, homoacetogens, hydrogenetrophic methanogens and aceticlastic methanogens. The symbiotic relationship among these microorganisms contributes to efficient anaerobic digestion and biogas production. [3,7,8].

76 The final phase, conducted by methane-forming bacteria, is the most crucial stage in biogas 77 production where the methanogens convert their primary substrates including acetate, hydrogen and carbon dioxide into methane. There are two pathways for methane formation, in 79 which approximately $75 \%$ of methane production derives from decarboxylation of acetate and 80 the remaining $25 \%$ originates from $\mathrm{CO}_{2}$ and $\mathrm{H}_{2}$ [9]. The methane-forming stage is also the 81 most sensitive and rate limiting step in the whole process since methane-forming bacteria 82 have a much slower growth rate compared to acid-forming bacteria, and are sensitive to 83 inhibitors such as ammonia, temperature, $\mathrm{pH}$ and other operational conditions. It is therefore 
84 imperative to retain sufficient slow-growing methanogenic bacteria and prevent active

85 biomass from being washed out from the fermenter, and to reduce inhibitory levels.

86

87

88

89

90

91

92

93

94

95

96

97

98

99

Complex Polymers

(Carbohydrates, Fats, Proteins )

Fermentative bacteria

Monomers and Oligomers (Sugars, Fatty acids, Amino acids)

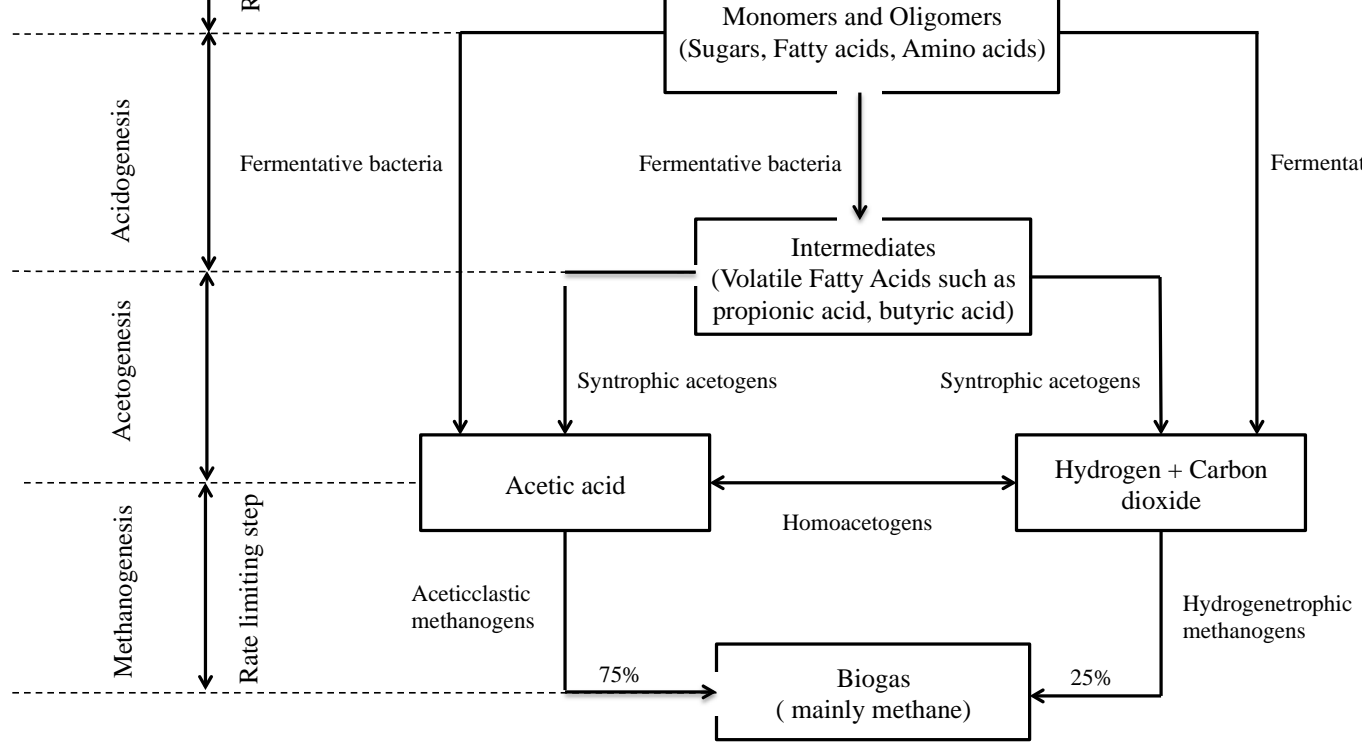

Fig. 1. A schematic diagram showing the comprehensive processes of biogas production from anaerobic processes [2,7].

\subsection{Biogas production by anaerobic membrane bioreactors (AnMBRs)}

The slow growing nature of methanogenic organisms and microbial complexity in the systems have made the operation of biogas fermenters difficult. The success of efficient biogas production depends on the effective retention of methanogenic bacteria in the reactor through decoupling of solids retention time (SRT) and hydraulic retention time (HRT) [10]. Research has mostly focused on retaining a high density of functioning anaerobic microorganisms, in order to achieve efficient biogas production. The most recent development in biogas production is the incorporation of anaerobic bioprocesses with 
membrane separation techniques in a membrane bioreactor (MBR), the purpose being to

101 increase biomass concentration extensively in the bioreactor. In an anaerobic membrane

102 bioreactor (AnMBR), high cell concentrations can be sustained under reasonably high

103 hydraulic load and sufficient mixing due to completely decoupling HRT from SRT [11].

104 Moreover, due to the sufficient retention of active microorganisms, AnMBRs generally

105 have high product concentration and productivity and relatively good toxic resistance, and

106 simplify the separation of product and/or biomass by using micro-filtration or ultra-filtration,

107 thus leading to an improved biogas production economy [6]. The reported biogas production

108 was well documented with the methane yield up to $0.36 \mathrm{~L} \mathrm{CH}_{4} / \mathrm{g} \mathrm{COD}_{\text {removed }}\left(0.30 \mathrm{~L} \mathrm{CH}_{4}\right.$

109 (STP)/g COD removed, the volume of methane produced at $0{ }^{\circ} \mathrm{C}$ Standard Temperature and 1

110 atm Standard Pressure) and the high methane content up to 90\% [12]. However, the

111 optimization of biogas production from AnMBRs has not gained much attention due to the as

112 yet under-developed nature of AnMBRs [7]. For extreme conditions, such as high salinity,

113 thermophilic temperature, high organic loading rate (OLR) and presence of toxicity,

114 membrane assisted anaerobic processes can be hampered and biogas productivity can be 115 compromised.

116 Several review papers on biogas production (most are recent) are available in the literature.

117 Ylitervo et al. [6] provided a general review of the MBR technology in ethanol and biogas

118 processes and summarized the development of MBRs and the membrane technologies for

119 these biofuels. Wang et al. [11] reviewed the progress in biogas technology in China and

120 briefly introduced AnMBRs as one of the emerging technologies. Mao et al. [2] discussed

121 advances in biogas production from anaerobic digestion in recent years and provided brief

122 information on AnMBRs for biogas production. He et al. [4] summarized the recent

123 performance of AnMBRs for methane and hydrogen production. Minardi et al. [13] reviewed

124 membrane applications for biogas production and purification processes. While these reviews

125 increased researchers' knowledge of AnMBRs for biogas production, they did not 
126 simultaneously either: extensively address detailed application concerns and potential

127 challenges encountered; or update the most recent studies. However, with the recent rapid

128 advances in AnMBR technology for bioenergy recovery, a detailed analysis of research 129 progress will be greatly appreciated.

130 The objective of this paper is to provide a comprehensive overview of such advances in 131 various AnMBRs, in view of both traditional and advanced reactor configurations for biogas 132 production. Moreover, with the focus on inhibitors and operational dilemmas, a detailed 133 assessment on the potential challenges that AnMBRs are facing is included in this paper. This 134 review provides perspectives on the outlook for an evolution in advanced AnMBRs 135 applications for more economically feasible and productive biogas yield.

\section{Types of AnMBRs for biogas production}

\subsection{Conventional AnMBRs}

$140 \quad$ 2.1.1. Completely stirred tank reactor (CSTR) AnMBRs

141 CSTR is by far the most frequently researched anaerobic process in AnMBR systems for 142 biogas production due to the ease of construction and operation. In most cases, CSTRs are in 143 cylindrical or rectangular shapes and employ mechanical turbines for mixing. Side-stream

144 membranes are often used, resulting in high bioreactor liquid turnover rates and a well-mixed 145 hydraulic flow regime. The potential for biological conversion from substrate to methane can 146 be greatly increased due to the prevailing high shear stress and intensive mixing [14, 15]. 147 Lab- and pilot-scale studies have been carried out with all three primary AnMBR 148 configurations: external side-stream membrane [16], submerged membrane [17], and 149 submerged membrane with external membrane tank [18]. In general, a CSTR coupled 150 membrane system is able to achieve a promising methane yield up to theoretical value [19].

151 Lin et al. [17] found a methane yield rate of $0.26 \mathrm{~L} \mathrm{CH}_{4} / \mathrm{g} \mathrm{COD}$ removed $\left(0.23 \mathrm{~L} \mathrm{CH}_{4}\right.$ (STP)/g 
$152 \mathrm{COD}_{\text {removed }}$ ) and high content of methane up to $85 \%$ when operating a pilot-scale submerged 153 anaerobic bioreactor (SAnMBR). The compact configuration of such module also allowed 154 more convenient biogas collection. The research on fermentative $\mathrm{H}_{2}$ production is also 155 typically conducted in CSTR-AnMBRs. Having the largest amount of energy per mass unit 156 than any other known substance $(142 \mathrm{~kJ} / \mathrm{g}), \mathrm{H}_{2}$ is an ideal energy carrier free from harmful 157 emissions during utilization as it is combusted to form only water. As the hydrogen 158 production stage occurs briefly prior to the methanogenic process, biohydrogen production 159 can be realized by inhibiting the methanogenesis phase using various intervention means. 160 These include the manipulation of hydrogen partial pressure, $\mathrm{pH}$ control, chemical inhibition, 161 and promotion of ferric-reducing conditions (the addition of $\mathrm{FeSO}_{4}$ solution) [6].

162 Previously, most research has been carried out in an external cross-flow type, but the 163 immersed type has become much more popular recently, due to requiring less energy 164 consumption and less need for fouling mitigation [20]. The carbon source conversion 165 efficiencies in the anaerobic hydrogen producing membrane bioreactor are promising with 166 two cases reaching $100 \%[21,22] . \mathrm{FeSO}_{4}$ concentration, in particular, was seen as a crucial 167 factor impacting on the dark fermentation pathway for $\mathrm{H}_{2}$ production from AnMBRs [21]. 168 Hydrogen productivity from the AnMBRs ranged from 2.5 [23] to $66 \mathrm{~L} / \mathrm{L} \cdot \mathrm{d}$ [24], and the 169 hydrogen content of biogas could reach as much as $62.6 \%$ [21].

170 However, to ensure a well-mixed flow regime and sufficient mass transfer, rigorous 171 mechanical mixing is required. Moreover, the disruption of particles as a result of sludge 172 recirculation through the membrane feed pump can have a negatively impact on the 173 orientation between acetogens and sensitive methanogens, thus limiting the essential 174 hydrogen transport for acquiring a superior specific methanogenic activity (SMA) [14, 25].

175 The impaired syntrophism often leads to a higher concentration of VFA in the system and 176 VFA inhibition is more severe particularly in the thermophilic system. Additionally, CSTR177 AnMBR usually operates at a lower biomass concentration (e.g. 5 g/L MLSS) compared to 
other high rate anaerobic reactors due to fouling control issues, which results in a lower OLR applied to the system, limiting the biomethane potential from high loading wastewater.

\subsubsection{Upflow anaerobic sludge blanket (UASB) AnMBRs}

The UASB concept was developed by Lettinga et al. in the 1970s for methane production.

The secret of such a novel high rate reactor design lies in its ability to: firstly, retain a high concentration of biomass in the form of well settlable methanogenic sludge granules in a thick dense sludge bed at the bottom of longitudinal reactor; and secondly, capture produced biogas through a gas/liquid/solid (GLS) separator at the top. Many researchers have attempted to combine UASB with membrane to optimize the joint benefits such as enhanced methane production and less fouling problems [26, 27]. Xie et al. [28] have investigated the feasibility of a submerged UASB-MBR system for recovering energy from kraft evaporator condensate at $36^{\circ} \mathrm{C}$ to $38^{\circ} \mathrm{C}$ for 9 months. The methane production rate of $0.35 \pm 0.05 \mathrm{~L} \mathrm{CH}_{4} / \mathrm{g} \mathrm{COD}_{\text {removed }}$ (0.31 $\pm 0.05 \mathrm{~L} \mathrm{CH}_{4}(\mathrm{STP}) / g \mathrm{COD}_{\text {removed}}$ ), which were very close to the theoretical yield of methane with $0.397 \mathrm{~L} \mathrm{CH}_{4} / \mathrm{g}$ COD removed at $37^{\circ} \mathrm{C}\left(0.350 \mathrm{~L} \mathrm{CH}_{4}(\mathrm{STP}) / \mathrm{g} \mathrm{COD}_{\text {removed }}\right.$ ), and the

193 methane content in the biogas, reached $90 \%$ in this study. Lin et al. [29] also reported a similar methane production rate and excellent fuel quality with $80-90 \%$ methane for both mesophilic and thermophilic SAnMBRs from kraft evaporator condensate treatment.

To assist with effective biomass retention, a hybrid UASB-MBR, in which fine fibers were

197 placed at the top of the sludge zone as a biofilter, served to treat real domestic wastewater for 198 biogas production at ambient temperature in Beijing, China [30]. Due to the sufficient 199 retention of biomass by the membrane (MLSS maintained as high as $21.5 \mathrm{~g} / \mathrm{L}$ ), this hybrid 200 Granular-AnMBR (G-AnMBR) system achieved maximum biogas production of $0.42 \mathrm{~L} / \mathrm{L} \cdot \mathrm{d}$, 201 and methane gas content of 66\%. UASB reactors for methane fermentation from low strength 202 wastewater at low and moderate temperatures are often encountered by a poor mixing regime, 203 which undermines biogas productivity due to a decrease in soluble COD treatment efficiency. 
204 The granulation process for UASB using non-granular seeding is also very lengthy, requiring

205 at the least a 3-month start-up period for stable biogas production. Direct Membrane 206 intervention into UASB eliminated the hydraulic selection pressure for sound granules. This 207 can negatively impact the granular sludge properties and hence the methane yield in the long208 term [14].

\subsubsection{Expanded granular sludge bed reactor (EGSB) AnMBRs}

211 EGSB reactors are tall reactors characterized by a higher ratio of height to width and 212 effluent recirculation, and they can provide a very high mixing intensity and sufficient

213 substrate-microbes contact induced by the high upflow force. However, to date, the studies on 214 the feasibility of the EGSB combined membrane process are limited. This is probably due to 215 the fact that manipulating sludge bed expansion in EGSB is relatively difficult due to the 216 absence of solid carriers under high hydraulic upflow force. The only study available was Chu 217 et al. [31] who reported biogas production ranging from 0.28 to $0.58 \mathrm{~L} / \mathrm{L} \cdot \mathrm{d}$, and $63-72 \%$ 218 methane at low HRT of 3.5 h from an EGSB reactor coupled with hollow fiber membrane 219 filtration for energy recovery from domestic wastewater at $15^{\circ} \mathrm{C}$. However, granules 220 fragmentation and sludge washout may occur due to the applied high upflow velocity $\left(\mathrm{U}_{\mathrm{v}}>4\right.$ $221 \mathrm{~m} / \mathrm{h}$ ), which may affect methane production. In addition, no granulation is expected in EGSB222 MBR, which would alter the properties of granular biomass and affect the biogas production 223 in the long-term.

\subsubsection{Anaerobic fluidized-bed membrane bioreactor (AFBR) AnMBRs}

AFBR is regarded as an effective anaerobic process to be coupled with membrane filtration due to its good mass transfer characteristics and retention of high concentration of 228 active microorganisms at short HRT lasting from a minutes to a few hours. Compared to 229 other gas-sparged AnMBRs, membrane fouling was successfully controlled through the 
energy efficient scouring effect of fluidized granular activated carbon (GAC) on the

231 membrane surface, resulting in fouling mitigation having significantly reduced energy costs

232 [32]. A two-stage anaerobic fluidized bed system is often required to fully reclaim methane

233 from wastewaters. Kim et al. [33] proposed a staged anaerobic fluidized membrane bioreactor

234 (SAF-MBR) system, which consisted of an AFBR and an anaerobic fluidized-bed membrane

235 bioreactor (AFMBR) for methane rebate from municipal wastewater primary-clarifier effluent.

236 The methane production from this system was reported as $4.11 \mathrm{~mol} \mathrm{CH} / \mathrm{m}^{3}\left(92.1 \mathrm{~L} \mathrm{CH}_{4}\right.$

$\left.237(\mathrm{STP}) / \mathrm{m}^{3}\right)$ with methane composition of $86 \%$ at HRT less than 5 h. Using only $30 \%$ of the

238 gaseous methane energy produced could satisfy total fluidization energy required for the

239 system, meaning such a SAF-MBR is a promising AnMBR for bioenergy production.

240 Similarly, Yoo et al. [34] and Dutta et al. [35] also worked on the SAF-MBRs and concluded

241 that the SAF-MBR system has excellent potential as a low-energy input, high-efficiency, and

242 cost-effective system using methane energy. This is despite the fact dissolved methane

243 representing $63 \%$ of the total methane production continued to represent a big issue that needs

244 to be solved if energy production is to increase [34].

245 Methane production is significantly affected by the temperature, and dissolved methane,

246 particularly in the winter period was a severe issue identified by researchers. Gao et al. [36]

247 investigated an integrated anaerobic fluidized-bed membrane bioreactor (IAFMBR) system

248 with simplified reactor operation and much smaller footprint compared with two-stage

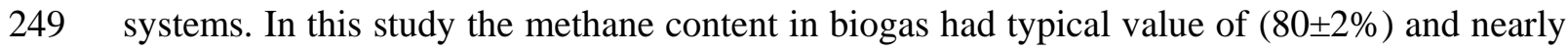

$25050 \%$ of the influent COD was converted into methane, of which $25 \%$ of produced methane

251 was lost in the liquid phase. As a result of the restrained organic degradation capacity of the

252 AFBR-AnMBRs, VFA accumulation and inhibition was found at shorter HRT, which reduced

253 the specific methane productivity. Moreover, Shin et al. [32] reported that the specific

254 acetoclastic methanogenic activity (SAMA) on the GAC was much lower than the enriched

255 acetoclastic cultures, indicating low levels of such organisms in the GAC VSS. Therefore, 
future research on biogas production optimization should consider the facilitation of attached

257 growth of syntrophic VFA-degrading acetogens and acetoclastic methanogens on GAC.

258

259 2.1.5. Jet flow anaerobic bioreactor (JFAB) AnMBRs

260 A jet flow anaerobic reactor has certain advantages when coupling with membrane 261 filtration to form an AnMBR for methane fermentation. The liquid circulation inside such a 262 reactor by using an inner tube and a nozzle system offers an adequate homogenization and 263 mass transfer [14]. Applying an UF membrane coupled to the JFAB, Saddoud et al. [37] 264 reported rich methane in biogas (70\%) with the average methane yield being $0.27 \mathrm{~L} \mathrm{CH}_{4} / \mathrm{g}$ $265 \mathrm{COD}_{\text {removed }}\left(0.24 \mathrm{~L} \mathrm{CH}_{4}(\mathrm{STP}) / \mathrm{g} \mathrm{COD}_{\text {removed }}\right)$ from domestic wastewater treatment. However, 266 in another study, Saddoud et al. [38] reported the inefficient methanization of such AnMBR

267 with the average methane yield not exceeding even $0.1 \mathrm{~L} \mathrm{CH}_{4} / \mathrm{g} \mathrm{COD}_{\text {removed }}\left(0.088 \mathrm{~L} \mathrm{CH}_{4}\right.$ 268 (STP)/g COD $_{\text {removed}}$ ). This was due to the considerable fluctuations in the substrate 269 composition and presence of toxic substances emanating from industrial effluents. Saddoud 270 and Sayadi [39], therefore proposed an innovative two-phase anaerobic digestion (TPAD) 271 system coupling anaerobic fixed bed reactor for optimized acidogenesis and the AnMBR for 272 optimized methanogenesis for biogas production from slaughterhouse wastewater. In this 273 combined process, the volatile fatty acid (VFA) inhibition was successfully overcome, and 274 biogas conversion was significantly improved with an average value of $0.31 \mathrm{~L} \mathrm{CH}_{4} / \mathrm{g}$ $275 \mathrm{COD}_{\text {removed }}\left(0.27 \mathrm{~L} \mathrm{CH}_{4}(\mathrm{STP}) / \mathrm{g} \mathrm{COD}_{\text {removed }}\right)$. Table 1 summarizes the key features and 276 advantages and challenges of conventional AnMBRs for biogas production. 
Table 1 Key features, advantages and challenges of conventional AnMBRs

\begin{tabular}{|c|c|c|c|}
\hline $\begin{array}{c}\text { Conventional } \\
\text { AnMBRs }\end{array}$ & Key features & Advantages & Challenges \\
\hline $\begin{array}{l}\text { CSTR- } \\
\text { AnMBRs }\end{array}$ & 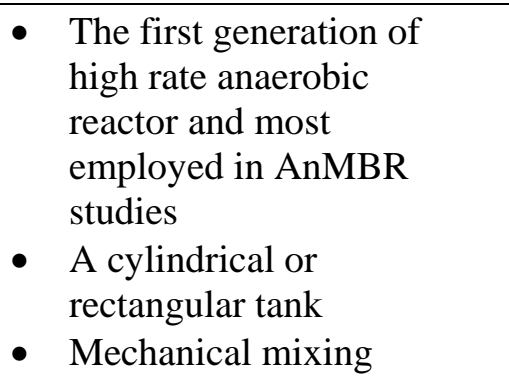 & $\begin{array}{l}\text { - Good substrate-sludge contact with slight } \\
\text { mass transfer resistance } \\
\text { - High liquid turnover rates and well-mixed } \\
\text { flow regime } \\
\text { - Enhanced biomethane potential due to } \\
\text { prevailing high shear stress and intensive } \\
\text { mixing }\end{array}$ & $\begin{array}{ll}\text { - } & \text { Rapid acidification and VFA } \\
\text { inhibition due to continuous mixing } \\
\text { and high shear stress } \\
\text { - } & \text { Negatively impacted SMA } \\
\text { - } & \text { Lower organic loading leads to lower } \\
\text { biomethane potential }\end{array}$ \\
\hline $\begin{array}{l}\text { UASB- } \\
\text { AnMBRs }\end{array}$ & $\begin{array}{l}\text { - A cylindrical or } \\
\text { rectangular column } \\
\text { - Biomass retention in the } \\
\text { form of granules } \\
\text { - Sufficient mixing } \\
\text { provided by liquid upflow } \\
\text { force and rising biogas } \\
\text { bubbles }\end{array}$ & $\begin{array}{l}\text { - } \quad \text { Good wastewater-biomass contact } \\
\text { - Superior quality of granular sludge for } \\
\text { - } \quad \text { Sigher biogas production } \\
\text { loading rates compared to flocculent sludge } \\
\text { bed reactor } \\
\text { - } \quad \text { Moderate tolerance to toxic compounds } \\
\text { - } \quad \text { No mechanical mixing device required } \\
\text { - } \quad \text { Reduced gas sparging demand }\end{array}$ & $\begin{array}{l}\text { - } \quad \text { Long start-up period } \\
\text { - Dead space and poor mixing at } \\
\text { psychrophilic conditions } \\
\text { - Elimination of hydraulic selection } \\
\text { pressure causes granules } \\
\text { deterioration and disintegration, and } \\
\text { unstable biogas production }\end{array}$ \\
\hline $\begin{array}{l}\text { EGSB- } \\
\text { AnMBRs }\end{array}$ & $\begin{array}{l}\text { - Tall column reactors with } \\
\text { smaller footprint and } \\
\text { effluent recirculation } \\
\text { - High upflow velocity } \\
(>4 \mathrm{~m} / \mathrm{h}) \text {, very high mixing } \\
\text { intensity, and efficient } \\
\text { biomass-substrate contact }\end{array}$ & $\begin{array}{l}\text { - Improved mass transfer in a compact } \\
\text { design } \\
\text { - Resolve issues with UASB such as } \\
\text { hydraulic short cuts, preferential flows, } \\
\text { poor mixing regime (dead zones), and } \\
\text { temperature constraints } \\
\text { - Effective in generating biogas from soluble } \\
\text { pollutants sources such as domestic }\end{array}$ & $\begin{array}{l}\text { - No granulation is expected, and this } \\
\text { may affect the granule sludge } \\
\text { properties and hence biogas } \\
\text { production } \\
\text { - Granules fragmentation and sludge } \\
\text { washout due to the high upflow } \\
\text { velocity }\end{array}$ \\
\hline
\end{tabular}


AFBR-

AnMBRs

JFAB-

AnMBRs
- Granular activated carbon as the medium for bacterial attachment and growth

- Tall column reactors with a smaller foot print and effluent recirculation

- Two stage submerged membrane configuration is most employed

- A greater surface area per unit of reactor volume

- An inner tube and a nozzle system for mixing

- Jet flow module wastewater, and wastewater containing

lipids and toxic/inhibitory compounds

- Higher organic and hydraulic loading and greater resistance to inhibitors for biogas production

- Much lower capital cost due to reduced reactor volume.

- Efficient in biogas production from pharmaceuticals and suspended particles of domestic wastewater

- A sound homogenization inside the reactor

- Sufficient mixing and compact design
- Two stage systems are often required for effective biogas production

- Dissolved methane remains as a big issue

- VFA accumulation and inhibition at shorter HRT.

- Low specific acetoclastic methanogenic activity (SAMA) on GAC

- VFA inhibition causing reduction in biogas production

- Ineffective in accommodating toxics and fluctuations in the feed 


\subsection{Modified AnMBRs}

\subsubsection{Anammox AnMBRs}

283

Anammox-AnMBR is a novel process combining energy recovery in the form of methane

284

with effective nitrogen management. Compared to the conventional

nitrification/denitrification process, anaerobic ammonium oxidization (Anammox) has many advantages such as high nitrogen removal, cost effectiveness and small footprint [40]. The Anammox reaction allows microbial oxidation of ammonium to form nitrogen gas $\left(\mathrm{N}_{2}\right)$ under anoxic conditions using nitrite as the electron acceptor [41]. Due to the complete separation of HRT and SRT by membrane, effective domestication and cultivation of the slow growing anammox bacteria was guaranteed in an Anammox-AnMBR. Dai et al. [42] investigated the simultaneous methane production and nitrogen removal from concentrated municipal wastewater by using a membrane-based process combining anaerobic digestion and nitritation-anammox under ambient temperature. The system achieved a stable methane yield of $0.223 \mathrm{~L} \mathrm{CH}_{4} / \mathrm{g} \mathrm{COD}_{\text {removed }}\left(0.206 \mathrm{~L} \mathrm{CH}_{4}(\mathrm{STP}) / \mathrm{g} \mathrm{COD}_{\text {removed }}\right.$ ) while a total nitrogen (TN)

295 removal efficiency of $81 \%$ was obtained in the sequential completely (CANON) MBR. This study concluded that the proposed process was a sustainable approach for biogas recovery and nitrogen removal. This research also revealed that further treatment is required to reclaim dissolved methane released into the environment as a powerful GHG, as well as to enhance the methane recovery efficiency.

Li et al. [40] investigated the sustainable operation of submerged Anammox AnMBR, and

301 found biogas sparging could greatly reduce small flocs attaching to the membrane to form a 302 cake layer, thereby alleviating membrane fouling. It should be noted that since nitrite and ammonia were converted to nitrogen gas by anaerobic ammonia-oxidizing bacteria (AnAOB),

304 methane composition in the biogas would be lower than that of other types of AnMBRs as a 305 result of the accumulation of produced $\mathrm{N}_{2}$ in the biogas. The interaction between AnAOB and 
methane-producing bacteria is still unknown, requiring further studies to maximize the

307 methane yield from the Anammox-AnMBR. Last but not least, the feed for the Anammox-

308 AnMBR contains high levels of ammonia, which can inhibit the production of methane.

\subsubsection{Anaerobic Dynamic Membrane bioreactors (AnDMBRs)}

311 Dynamic membrane (DM) technology is a new approach for resolving problems such as

high cost of membrane modules, low membrane flux, and rapid membrane fouling encountered in conventional AnMBR processes. In an AnDMBR, the solid-liquid separation

314 is mainly accomplished by the cake layer (e.g., dynamic membrane) formed on low cost

315 supporting materials such as meshes and fabrics with macropores [43]. Such a DM transforms one of the most critical disadvantages of AnMBRs, namely membrane fouling, into a competitive advantage. When the dynamic membrane is seriously fouled, the cake layer can be easily removed, cleaned and then replaced by a new deposited layer, thus significantly reducing the membrane cost [44]. The cleaning process and its frequency are determined by the dynamic membrane material and chemical resistance of the filters [45]. Alibardi et al. [46] developed a bench scale anaerobic dynamic MBR using a large pore-sized mesh at $200 \mu \mathrm{m}$. They observed varying biogas production with maximum value of $1 \mathrm{~L} / \mathrm{d}$ and methane content fluctuating from $50 \%$ to $79 \%$, which was mainly due to the variability of COD removal and HRT during operation. Low CFV (due to the use of larger pore size) contributed to the sustainable aspect of the AnDMBR by reducing high energy input and led to improved methanogenic activity by minimizing the shear stress on the biomass. Methane oversaturation in the effluent was reported in the study. Due to the higher methanogenic activities of the cake layer formed on the external dynamic membrane module, a great amount of biogas was produced by the membrane unit and subsequently released with the effluent stream. 
wastewater. Average methane yields of $0.31 \pm 0.02 \mathrm{~L} \mathrm{CH}_{4} / \mathrm{g} \mathrm{COD}_{\text {removed }}\left(0.27 \pm 0.02 \mathrm{~L} \mathrm{CH}_{4}\right.$

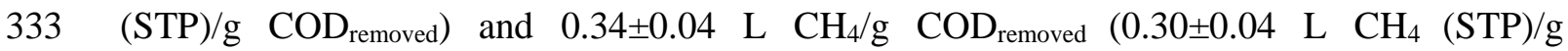

334 COD $_{\text {removed }}$ ) were reported at SRTs of 20 days and 40 days, respectively, which were very

335 close to the maximum theoretical value. Methane was solubilized in the permeate. The study

336 also revealed that strong shear stress as a result of biogas sparging might create a physical

337 interruption on the syntrophic anaerobes associated with methane forming, based on the fact

338 that SMAs of the bulk sludge samples were lower than those of the seed sludge at both SRTs.

339 Xie et al. [47] achieved promising average methane yield at $0.34 \mathrm{~L} / \mathrm{g} \mathrm{COD}_{\text {removed }}\left(0.30 \mathrm{~L} \mathrm{CH}_{4}\right.$

340 (STP)/g COD removed $_{\text {) }}$ and methane content of 70-90\% using Dacron mesh (pore size $=40 \mu \mathrm{m}$ )

341 in the AnDMBR for the treatment of raw leachate, high heavy metal concentrations, and high

342 total ammonium concentration above $3000 \mathrm{mg} / \mathrm{L}$. Based on the archaeal taxonomic

343 identification, aceticlastic methanogens were the dominant functional group that produced

344 methane, while hydrogenotrophic methanogens were eliminated at the end of the experiment

345 when ammonium inhibition was observed.

346

\subsubsection{Anaerobic Membrane distillation bioreactors (AnMDBRs)}

Membrane distillation (MD) is a thermally driven separation process in which water vapor

transfers across a thermal gradient through a hydrophobic, microporous membrane such as

350 polypropylene (PP), polyvinylidene fluoride (PVDF) or polytetrafluoroethylene (PTFE)

351 membranes to form water [48, 49] The competitive advantages of anaerobic processes can be

352 readily utilized when they are combined with the MD process, as the mesophilic or

353 thermophilic operation for the methane fermentation can allow no or less heating requirement

354 for the subsequent MD treatment [49]. AnMDBRs usually require significantly reduced

355 footprints and provide complete retention of incoming organics and microorganisms for

356 maximum bioconversion from waste to energy in the form of biogas [48-50]. The other

357 highlight of the AnMDBR treatment is the complete removal of total phosphorus for the 
purpose of controlling eutrophication, which has been recognized as a significant

359 environmental and ecological concern for decades [49].

360 In a typical AnMDBR system, biogas can be recovered from the system for gas sparging 361 for mixing and fouling control purposes, and additional gas can be utilized for heating and 362 energy use [48]. However, post-treatment is required to recover ammonium nitrogen and 363 methane dissolved in the permeate. Smith et al. [51] reported methane loss in the liquid phase 364 from the anaerobic MBR could be as much as $30 \%$ and $50 \%$ at $35^{\circ} \mathrm{C}$ and $15^{\circ} \mathrm{C}$, respectively, 365 due to the fact that the solubility of methane gas decreases in response to temperature increase.

366 In an AnMDBR, most of the methane is more likely to exist in the gas phase, thus allowing 367 much easier methane extraction and recovery. Moreover, the dissolved methane is transported 368 with the permeate via the slower gas diffusion process in the thermally-driven AnMDBR, 369 whereas other AnMBRs are mostly pressure-driven, the methane gas would rapidly pass into 370 the permeate across the porous membrane via poiseuille flow. Therefore, dissolved methane 371 in the permeate from the anaerobic MDBR will most likely be much less than those from the 372 other AnMBRs [48]. Xie et al. [49] hybridized anaerobic moving bed biofilm reactor 373 (AMBBR) with the MD process for the treatment of domestic wastewater. A small quantity of 374 biogas with methane content at 58\%-72\% was produced from the AMMBR while no other 375 biogas data was available from the MD process. Further research regarding biogas production 376 from the AnMDBR and the effects of MD process on the methane-producing species would 377 be valuable so that the benefits of AnMDBR in the sense of bioenergy recovery can be fully 378 explored. It would also be possible to identify possible challenges in biogas production from 379 AnMDBRs.

2.2.4. Anaerobic osmotic membrane bioreactors (AnOMBRs)

AnOMBRs constitute a novel integrated system combining AnMBRs with the forward osmosis (FO) process for effective retention of smaller sized contaminants and prolonging of 
their residence time in the reactor, thus leading to improved biodegradation efficiency and

385 biogas yield in one integrated system [52]. In an AnOMBR the FO membrane is usually used,

386 in which water flows from a low-osmotic- pressure feed solution (FS) to a high-osmotic-

387 pressure draw solution (DS) across a semi-permeable membrane. One of the greatest

388 advantages of the FO process is that no energy input is required to drive the filtration process

389 as compared to traditional energy-intensive pressure-driven separation processes such as

390 MF/UF. Gu et al. [52] evaluated the extent of energy recovery in the form of methane gas

391 from an AnOMBR when treating low-strength wastewater at mesophilic temperature. A

392 promising methane production of $0.25-0.3 \mathrm{~L} \mathrm{CH}_{4} / \mathrm{g} \mathrm{COD}_{\text {removed }}\left(0.22-0.27 \mathrm{~L} \mathrm{CH}_{4}\right.$ (STP)/g

393 COD $_{\text {removed}}$ ) was obtained although a loss of methane in the effluent and a high salinity

394 environment (10 mM-200 mM NaCl equivalent) was discovered in the system. Although the

395 salt, alkalinity and ammonia accumulations in the reactor were reported to have no effects on

396 the bioactivity and biogas production, a long-term examination of salt inhibition, $\mathrm{pH}$ stability

397 and ammonia inhibition on the biogas production still requires a further assessment.

398 Chen et al. [53] demonstrated the feasibility of energy recovery from a FO-AnMBR 399 system and reported an average methane yield value of $0.21 \mathrm{~L} \mathrm{CH}_{4} / \mathrm{g} \mathrm{COD}_{\text {removed }}\left(0.19 \mathrm{~L} \mathrm{CH}_{4}\right.$

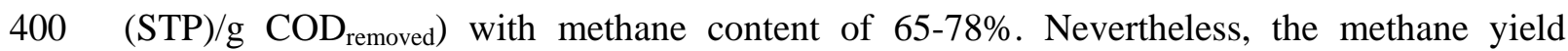
401 represented only $58 \%$ of the maximal theoretical value due to the loss of methane dissolved in 402 the permeate as well as the inhibition of methanogenic activity under accumulated salinity 403 environment. They also pointed out that under high osmotic conditions, anaerobic biomass 404 tended to consume substrate to produce compatible solutes through osmoregulation and 405 extracellular polysaccharides in order to survive. Therefore, a further investigation of 406 salinity's effect on the microbial kinetics and methanogenic activity is required to optimize 407 the biogas production rate. Other challenges associated with the FO-AnMBR were the 408 disposal of inorganic-rich supernatant, and the membrane’s low tolerance to high temperature 409 solution and biological attachment to sustain stable biogas production in the long-term. 
2.2.5. Anaerobic membrane sponge bioreactors (AnMSBRs)

412 For an AnSMBR, the medium for bacterial attachment and growth is low-cost 413 polyurethane sponges. These sponges represent a viable mobile carrier in many MBR 414 technologies due to their high porosity and endurance, which can immobilize microorganisms 415 and remove organics and nutrients effectively. Their sound mechanical features in relation to 416 membrane scouring are another advantage to counter-attack membrane fouling due to the 417 continuous rubbing behavior of the moving media. Kim et al. [54] investigated both single 418 and two-stage sponge-submerged AnMBRs using an anaerobic rotary disk MBR (ARMBR) 419 without the membrane cleaning and replacement. They found that disk rotation contributed to 420 enhanced shear force and mass transfer of media, and led to the effective collision between 421 the sponge and membrane surface, thus successfully alleviating fouling and enhancing the 422 membrane permeability in the ARMBR. Apart from the disk rotation, sponges were utilized 423 to maintain microbial growth in the mobile phase as well as effectively control membrane 424 fouling. The reported methane production yield and methane composition in the single system 425 were $12 \%$ and $13 \%$ higher than those of two-stage systems. Therefore it was suggested that 426 the single ARMBR process was superior to the two-stage process due to higher energy 427 production in the more simplified configuration of the single system. Further research on the 428 effects of sponge size, density and shape, and shear stress of the disk rotation on the 429 bioactivity and biogas production are very much appreciated.

\subsubsection{Gas-lifting AnMBRs (Gl-AnMBRs)}

Gl-AnMBR is considered to be an advanced hybrid treatment process that combines anaerobic bioprocess with low-pressure membrane filtration. In both external cross-flow and

434 immersed configurations of conventional AnMBRs, considerable energy input is needed for 435 the gas scrubbing requirements of membrane. A Gl-AnMBR, instead, applies the airlift 
configuration by using headspace biogas for gas lift to maintain a reasonable membrane flux

437 with minimal energy input, thus optimizing the overall energy footprint of AnMBRs. The

438 utilization of biogas-assisted mixing also facilitates the methane stripping from the bulk liquid,

439 avoiding super-saturation, and allowing a minimum amount of methane dissolved in the

440 permeate [55]. Prieto et al. [56] developed a Gl-AnMBR and evaluated its ability to recover

441 resource from sewage. This suspended-growth bioreactor coupled to a tubular PVDF UF

442 membrane was able to produce $4.5 \mathrm{~L} / \mathrm{d}(0.28 \mathrm{~L} / \mathrm{gVSS} \mathrm{d})$ biogas, which can be used for

443 membrane scrubbing and energy recovery. Biogas injection was introduced at the bottom of

444 this system where biogas was combined with the sludge to form a two-phase (liquid-gas)

445 flow through the lumen of vertically-placed tubular membranes. The introduction of biogas

446 bubbles into the membrane feed significantly reduced the membrane fouling because of the

447 increased shear force and turbulence over the membrane surface. The ascending biogas

448 bubbles also enhanced the sludge filterability by decreasing the feed density. Therefore,

449 pumping cost for feed flow and permeate extraction was minimized, meaning there were less

450 energy expenses. However, the biogas recirculation for scouring generated high shear force,

451 which was reported to negatively impact on the SMA and subsequently compromise biogas 452 production.

453

454

455

456

457

458

459

460

461

\subsubsection{Vibrating AnMBRs (V-AnMBRs)}

Membrane fouling is typically controlled by the recirculation of biogas to create shear and turbulence on the membrane surface [57]. However, the high cost of gas pumping, the difficulty of operating gas sparging in certain cases, and its shear stress on the anaerobic microbes remain as major concerns for the gas-sparged AnMBRs. V-AnMBRs, which utilize effective vibratory shear for enhancing the shear at the membrane surface, have attracted the interest of researchers in recent years. Kola et al. [58] introduced a transverse vibration as an innovative membrane fouling mitigation strategy into a membrane coupled UASB reactor. 
462 Based on the observations of significantly increased critical flux and more reversible fouling 463 as compared with conventional fouling control, this study proved transverse hollow fiber 464 membrane vibration provided alternative enhancement of mass transfer. This type of 465 membrane vibration also created vortices in the wake of the vibrating surface, thus facilitating 466 the permeate filtration where gas sparging was often unfavorable. By appropriately 467 incorporating periodical backwash/relaxation with vibrational filtration, such a V-AnMBR 468 would be a promising technology for biogas production. However, the effects of vibratory 469 shear stress on the methane-producing microorganisms require further analysis for the optimal 470 biogas production.

471 Vrieze et al. [57] investigated a novel V-AnMBR using a magnetically induced vibration 472 membrane filtration system as the solo shear enhancement device in anaerobic digestion for 473 fouling mitigation. The biomethanation performance and membrane fouling of the V-AnMBR 474 was compared with a conventional SAnMBR with biogas scouring (known as NV-AnMBR). 475 Similar $\mathrm{CH}_{4} / \mathrm{CO}_{2}$ ratios (around 1.89) in the biogas were observed from both reactors only 476 when treating diluted molasses wastewater but the V-AnMBR resulted in a noticeable 477 increase in transmembrane pressure and failed to prevent the formation of a cake layer due to 478 the absence of a mixing system. The authors also justified that V-AnMBR is still a promising 479 technology and can be applicable if conventional mixing devices or other measures can be 480 implemented to avoid cake layer build-up. VFA accumulation and a decline in methane 481 production were reported when concentrated molasses were applied, which indicated the 482 inhibitory effects of concentrated molasses on biomethanation.

\subsubsection{Anaerobic bio-entrapped membrane bioreactors (AnBEMRs)}

485 In view of fouling being the major concern in AnMBRs, the anaerobic bio-entrapped membrane reactor (AnBEMR) has been developed as an alternative to the conventional 487 AnMBRs, particularly those with high biomass concentrations. The competitive advantage of 
488 the entrapped biomass technique was the superior simultaneous removal of carbon and 489 nitrogen within a simplified single throughput bioprocess. Its robust capacity to tackle 490 complex organic compounds, and handle high dissolved organics loading at low suspended 491 biomass concentration was observed in the aerobic bioprocesses [59]. In addition, when 492 combining the entrapped biomass technique with the membrane, membrane fouling can be 493 greatly reduced since less soluble organics and suspended biomass were produced in the bio494 entrapped system.

$495 \mathrm{Ng}$ et al. [59], as the sole example in the literature, proposed a novel lab-scale anaerobic 496 bio-entrapped membrane reactor (AnBEMR) packed with bio-ball carriers. In their study, 497 both the traditional AnMBR and AnBEMR were tested for biogas production from 498 pharmaceutical wastewater treatment. The authors found that the AnBEMR was able to 499 produce around 15\% more methane than the AnMBR $\left(0.142 \pm 0.034 \mathrm{~L} \mathrm{CH}_{4} / \mathrm{g} \mathrm{COD}_{\text {removed }}\right.$ $500\left(0.130 \pm 0.034 \mathrm{~L} \mathrm{CH}_{4}(\mathrm{STP}) / \mathrm{g} \mathrm{COD}_{\text {removed }}\right)$ while that of the AnBEMR was $0.159 \pm 0.035 \mathrm{~mL}$ $501 \mathrm{CH}_{4} / \mathrm{g} \mathrm{COD}_{\text {removed }}\left(0.145 \pm 0.035 \mathrm{~L} \mathrm{CH}_{4}(\mathrm{STP}) / \mathrm{g} \mathrm{COD}\right.$ removed$\left.)\right)$ after a 70 -day start-up period. 502 However, both systems encountered the inhibition of methane yield due to organic 503 overloading, high salinity conditions and accumulation of toxic organics when increasing 504 OLRs up to $34.0 \pm 2.7 \mathrm{~kg} \mathrm{COD} / \mathrm{m}^{3} \cdot \mathrm{d}$. Furthermore, the AnBEMR showed a longer membrane 505 filtration operating period than the AnMBR due to the release of smaller concentrations of 506 EPS and SMP, and lower suspended biomass concentration. Table 2 summarizes the key 507 features and advantages and challenges of modified AnMBRs for biogas production. 508 
Table 2 Key features, advantages and challenges of modified AnMBRs

\begin{tabular}{|c|c|c|c|}
\hline $\begin{array}{l}\text { Modified } \\
\text { AnMBRs }\end{array}$ & Key features & Advantages & Challenges \\
\hline $\begin{array}{l}\text { Annamox- } \\
\text { AnMBRs }\end{array}$ & $\begin{array}{l}\text { - } \text { Completely autotrophic } \\
\text { nitrogen removal } \\
\text { - } \text { Anammox bacteria } \\
\text { - Homogeneous } \\
\text { distribution of substrates } \\
\text { and biomass } \\
\text { - Anammox bacteria in } \\
\text { forms of flocs or } \\
\text { granules }\end{array}$ & 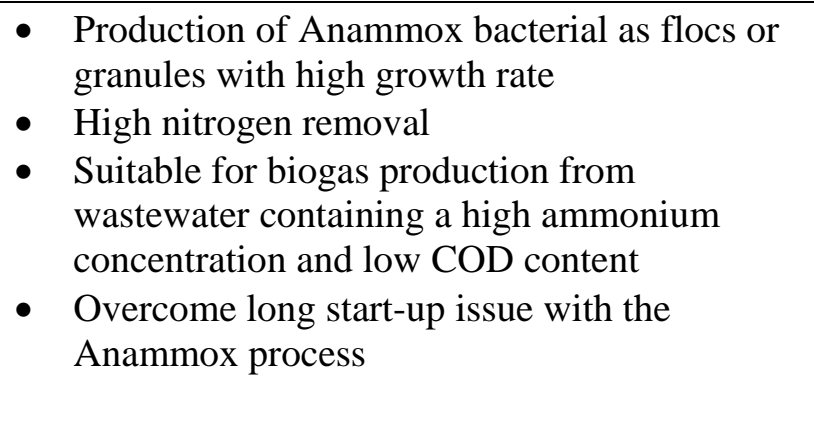 & $\begin{array}{l}\text { - } \text { Dissolved methane } \\
\text { - } \text { AnAOB compete with methane- } \\
\text { producing bacteria } \\
\text { - } \text { Methane composition can be altered } \\
\text { due to the production of nitrogen gas } \\
\text { - Ammonia inhibition }\end{array}$ \\
\hline AnDMBRs & $\begin{array}{l}\text { - Dynamic membrane was } \\
\text { formed on the supporting } \\
\text { materials such as meshes } \\
\text { and fabrics with } \\
\text { macropores }\end{array}$ & $\begin{array}{l}\text { - Much lower capital costs for membrane and } \\
\text { its cleaning and replacement } \\
\text { - Higher membrane flux } \\
\text { - } \text { Reduced energy consumption and shear stress } \\
\text { on the biomass by using low CFV } \\
\text { - Cope well with large OLR, high heavy metal } \\
\text { and high ammonium concentrations } \\
\text { - Promising methane production due to the } \\
\text { higher methanogenic activity }\end{array}$ & $\begin{array}{l}\text { - Methane oversaturation in the } \\
\text { - } \text { Sermeate } \\
\text { strong shear stress due to biogas } \\
\text { methanogenic activity } \\
\text { - Biogas escape from the external } \\
\text { membrane unit and effluent collection } \\
\text { vessel } \\
\text { - Ammonium inhibition on } \\
\text { hydrogenotrophic methanogens }\end{array}$ \\
\hline AnMDBRs & $\begin{array}{l}\text { Thermally-driven MD } \\
\text { process using } \\
\text { microporous } \\
\text { hydrophobic membranes } \\
\text { - The organic retention } \\
\text { times much greater than }\end{array}$ & $\begin{array}{l}\text { - Complete retentions of non-volatile organics } \\
\text { - Lower operating pressures than conventional } \\
\text { pressure-driven membrane processes } \\
\text { - Particularly suitable for treating refractory } \\
\text { - } \quad \text { organics which require a long residence time } \\
\text { - Complete rejection of total phosphorus }\end{array}$ & $\begin{array}{l}\text { High energy requirement for heating, } \\
\text { and uneconomical for large-scale } \\
\text { applications } \\
\text { - Post-treatment required to recover } \\
\text { methane from the permeate }\end{array}$ \\
\hline
\end{tabular}




\begin{tabular}{|c|c|c|c|}
\hline & $\begin{array}{l}\text { the hydraulic retention } \\
\text { time } \\
\text { - Thermophilic bacteria at } \\
\text { about } 50^{\circ} \mathrm{C} \\
\text { - Stable fluxes can be } \\
\text { sustained }\end{array}$ & $\begin{array}{ll}\text { - } & \text { Shorter start-up time } \\
\text { - } & \text { Less dissolved methane }\end{array}$ & \\
\hline AnOMBRs & $\begin{array}{l}\text { - High retention forward } \\
\text { osmosis semi-permeable } \\
\text { membrane } \\
\text { - } \begin{array}{l}\text { Draw solution (such as } \\
\text { seawater) required } \\
\text { - }\end{array} \\
\text { Separation driven by } \\
\text { osmotic pressure } \\
\text { difference } \\
\text { - High rejection capacity }\end{array}$ & $\begin{array}{l}\text { - Better organic removal and higher } \\
\text { biomethane potential } \\
\text { - Suitable for methane fermentation from dilute } \\
\text { - } \quad \text { Rastewater under mesophilic conditions } \\
\text { acidification of alkalinity and avoiding reactor } \\
\text { - Complete total phosphorus removal and } \\
\text { - Partial ammonia and total nitrogen removal } \\
\text { Promising methane production }\end{array}$ & $\begin{array}{l}\text { - Possible effects of alkalinity, salt and } \\
\text { ammonia accumulation on the long } \\
\text { term stable biogas production } \\
\text { - The inorganic-rich supernatant } \\
\text { disposal } \\
\text { - Membrane's low endurance to } \\
\text { biological attachment and high } \\
\text { temperature solution for the long time } \\
\text { operation }\end{array}$ \\
\hline AnSMBRs & $\begin{array}{l}\text { Rotary disk-supporting } \\
\text { media for membrane } \\
\text { fouling control } \\
\text { - Sponges for sustaining } \\
\text { microbial growth and } \\
\text { fouling control }\end{array}$ & $\begin{array}{l}\text { - } \quad \text { Enhanced membrane permeability } \\
\text { - Low cost sponge media for mobile carrier } \\
\text { - Successful membrane fouling control } \\
\text { (scouring) without any membrane cleaning }\end{array}$ & $\begin{array}{l}\text { - Limited data available to examine the } \\
\text { biogas production from such } \\
\text { AnSMBRs } \\
\text { - Further studies required to determine } \\
\text { the optimal sponge characteristics for } \\
\text { the optimized biogas production }\end{array}$ \\
\hline $\begin{array}{l}\text { Gl- } \\
\text { AnMBRs }\end{array}$ & $\begin{array}{l}\text { - Two-phase flow in the } \\
\text { membrane unit } \\
\text { - Enhanced sludge } \\
\text { retentate recirculation }\end{array}$ & $\begin{array}{l}\text { - } \quad \text { Lower cross-flow velocity } \\
\text { - Biogas-assisted mixing can help with } \\
\text { reducing methane super-saturation }\end{array}$ & $\begin{array}{l}\text { - Helium gas required for the start-up } \\
\text { - Continuous scouring can cause } \\
\text { varying gas equilibriums, methane } \\
\text { oversaturation and changing pH } \\
\text { - } \begin{array}{l}\text { High shear stress on the methanogens } \\
\text { due to the gas recirculation }\end{array}\end{array}$ \\
\hline
\end{tabular}


V-

AnMBRs

- Membrane vibration system for fouling

control instead of

traditional gas-sparging

means

AnBEMRs

- Biomass entrapped in the bio-carriers/bio-balls
- No mixing system required

- Suitable for fouling control when biogas gassparging is not feasible

- No biogas sparging shear stress on the biomass

- Better organic removal and higher methane yield than conventional AnMBRs

- High organic loading

- Significantly reduced fouling

- Suitable for claiming biomethane from complex wastewater (pharmaceuticals)
- Inhibited methanogenic activity due to high salinity and toxic sulfide levels

- Vibratory shear stress may affect the microbial activity for biogas production and requires further investigation

- Acidogenesis and methanogenesis inhibition at high salinity conditions and organics overloading

- Dissolved methane causes the lower methane yield

- Long start-up period 


\section{Inhibitors of biogas production}

512

\section{$513 \quad$ 3.1. Ammonia}

514

515 During methane fermentation, ammonia is generated by the biodegradation of the 516 nitrogenous compounds mostly in the form of proteins [60]. As ammonia concentration grows 517 above $3500 \mathrm{mg} / \mathrm{L}$, methane yield starts to suffer from decreasing below the theoretical value

518 [61]. As ammonia concentrations climb up to the values of $4051-5734 \mathrm{mg} \mathrm{NH}_{3}-\mathrm{N} \mathrm{L}^{-1}$, the 519 methanogenic bacteria can lose $56.5 \%$ of its activity. Ammonia inhibition includes the 520 increase of maintenance energy requirement, a change in the intracellular $\mathrm{pH}$, and inhibition 521 of a specific enzyme reaction. Free ammonia $(\mathrm{FA})\left(\mathrm{NH}_{3}\right)$ is more toxic than ionized ammonia $522\left(\mathrm{NH}_{4}{ }^{+}\right)$because it is able to penetrate through the cell membrane, resulting in the disruption of 523 cellular homeostasis, potassium deficiency and/or proton imbalance [60]. A higher 524 temperature and $\mathrm{pH}$ value can exacerbate the inhibition by releasing more FA [62]. Release 525 of ammonia is a primary concern for a high rate or intensified process such as AnMBR 526 treating high strength waste, where shorter HRT and higher OLR may cause substrate and 527 inhibitory intermediates to accumulate in the reactor [63].

528 Measures to minimize ammonia inhibition are demanded especially for thermophilic 529 methane fermentation from AnMBRs. Kanai et al. [61] proposed the Kubota Submerged 530 Anaerobic Membrane Bioreactor, in which the membranes could retain methanogenic 531 bacteria while ammonia could be filtered out with the permeate, allowing the efficient 532 production of methane from Japanese garbage with high protein levels (TN concentration at $53310,000 \mathrm{mg} / \mathrm{L})$. The recovered energy from this process was well above the overall energy 534 consumption, enabling such a SAnMBR to be a net energy producer. Meabe et al. [62] 535 suggested that the acclimatization of biomass due to the high SRT in the AnMBR system 
536 could affect the degree of ammonia inhibition, and no critical inhibition by ammonia was

537 expected in the their mesophilic and thermophilic study.

538 Jensen et al. [63] also reported a successful methanation process from anaerobic digestion

539 of slaughterhouse wastewater containing high proteins using a pilot-scale AnMBR. They

540 found over 95\% of COD in the wastewater feed was converted into biogas with 70\% methane,

541 and $78-90 \%$ of nitrogen was released to the permeate as ammonia, which meant ammonium

542 inhibition was minor in this system. Landfill leachate also features high concentrations of

543 organic contaminants and ammonia, which can be problematic when used for biogas

544 production. Xie et al. [47] have successfully applied an AnDMBR for biomethane production

545 with average methane yield at $0.34 \mathrm{~L} / \mathrm{g} \mathrm{COD}$ removed $\left(0.30 \mathrm{~L} \mathrm{CH}_{4}(\mathrm{STP}) / \mathrm{g} \mathrm{COD}\right.$ removed $)$ from high

546 strength landfill leachate digestion. Although free ammonium nitrogen (FAN) concentration

547 was completely inhibitory in this case, detrimental effects were not observed on the

548 performance due to the microorganisms’ adaption to high free ammonia concentrations. The

549 authors also suggested an interesting finding that the acetate-consuming methanogens were

550 less inhibited than hydrogen utilizing methanogens, despite high ammonium concentrations in

551 the reactor (over $3000 \mathrm{mg} / \mathrm{L} \mathrm{NH}_{3}-\mathrm{N}$ at mesophilic conditions). This has proved to be

552 controversial to other researchers $[60,64]$ indicating that aceticlastic methanogens were more

553 sensitive to ammonium inhibition compared with hydrogenotrophic methanogens.

554

555

3.2. Sulfide

556

557 Problems associated with the methane fermentation of sulphate-rich wastes are the toxicity

558 of sulphide to anaerobic microorganisms and the competition for the influent COD from the

559 sulphate reducing bacteria (SRB) (approx. $2 \mathrm{~g} \mathrm{COD} / \mathrm{g} \quad \mathrm{SO}_{4}-\mathrm{S}_{\text {removed }}$ ), which suppresses

560 methane productivity $[60,65,66]$. In particular, methane production from municipal

561 wastewater can be challenging because it can be easily characterized by low $\mathrm{COD} / \mathrm{SO}_{4}$-S

Challenges in biogas production from anaerobic membrane bioreactors, Renewable Energy, 98, 120-134, 2016.27 
ratios. The fierce competition between methane producing bacteria (MPB) and SRB can

563 negatively impact on the quantity and quality of the biogas produced. Although it is evident

564 that the AnMBRs are more resistant to toxics due to the sufficient SRTs for methanogens,

565 many studies have reported increased operational costs during the treatment of high sulphate

566 containing wastewaters by the AnMBR, especially at psychrophilic conditions and lower

567 SRTs. Both Ferrer et al. [65] and Pretel et al. [66] concluded that AnMBR systems

568 represented more energy surplus potential, thus being a net energy producer when treating

569 low-sulphate municipal wastewater in warm/hot climates. The cost savings of up to $28 \%$

570 (Ferrer et al., [65]) in treating low-sulphate can be achieved as compared to the scenario with

571 sulphate-rich municipal wastewater. Liao et al. [12] reported the complete inhibition of

572 biological activity caused by feed toxic shock (high concentration of $\mathrm{H}_{2} \mathrm{~S}$ in feed) in a

573 thermophilic SAnMBR with mesophilic sludge as the inoculum. Thus, the pretreatment of the

574 feed should be in place to remove toxic sulfur substances so that the biological activity of

575 thermophiles can be maintained. Gimenez et al. [67] also observed a low methane yield at

$5760.069 \mathrm{~L} / \mathrm{g} \mathrm{COD}_{\text {removed }}\left(0.061 \mathrm{~L} \mathrm{CH}_{4}(\mathrm{STP}) / \mathrm{g} \mathrm{COD}_{\text {removed}}\right.$ ) from a pilot-scale mesophilic

577 SAnMBR treating wastewater with a low $\mathrm{COD} / \mathrm{SO}_{4}-\mathrm{S}$ ratio, and this was mainly attributed to

578 the SRB competition for $90 \%$ of influent COD. The methane recovery efficiency from

579 SAnMBRs was greatly influenced by sulphate content in urban wastewater, and higher biogas

580 production would be expected if high $\mathrm{COD} / \mathrm{SO}_{4}-\mathrm{S}$ or no sulphate were present in the substrate

581 [55]. The effective countermeasures to sulfide toxicity include the dilution of the wastewater,

582 and the implementation of sulfide removal techniques such as physico-chemical measures

583 (stripping), chemical reaction (coagulation, oxidation, precipitation), and biological

584 conversions (micro-aerobic sparging and partial oxidation to sulfur) [60]. Acclimatization of

585 MPB to free $\mathrm{H}_{2} \mathrm{~S}$ to increase the tolerance of aceticlastic and hydrogenotrophic MPB to

586 sulfide can also be a possible solution. Nevertheless, above-mentioned sulfide toxicity control 
techniques require further research to obtain valuable data from AnMBRs, in order to validate

588 their applicability and effectiveness in sulfide control.

589 On the other hand, methanogenic activities are not inhibited if the ratio of COD/sulphate in

590 substrate is higher than 10, and low concentrations of sulphate and sulphide are also necessary

591 for effective biogas production [68,69]. Li et al. [70] compared the performance of two

592 AnMBRs with and without the addition of sulphate for the anaerobic co-digestion of coffee

593 grounds, milk and waste activated sludge. They concluded that sulphate addition (at a

$594 \mathrm{COD} / \mathrm{SO}_{4}{ }^{2-}$ ratio of 200:1 to $\left.350: 1\right)$ wielded positive effects on propionate degradation and

595 methane fermentation in a thermophilic AnMBR at higher OLRs. Without the addition of

596 sulphate, the thermophilic AnMBR system at higher OLRs entered a "sub-health state” as a

597 consequence of propionate acid accumulation.

598

599

\subsection{Salinity}

600

601

602

The presence of high salt concentrations is common in many saline wastes from fish and seafood processing, chemical, petroleum and pharmaceutical industries. High salinity can

603 cause bacterial cells to dehydrate due to the osmotic pressure. With its toxic effects on non-

604 adapted biomass mainly attributed to cations, high salinity is regarded as one of the most

605 important factors influencing methane fermentation processes [60]. Enzyme inhibition, cell

606 activity decline and plasmolysis are the typical manifestations of salt stress on anaerobic

607 microbes [10]. Ng et al. [59] investigated strong salinity conditions’ inhibitory effect on

608 methane yield from both conventional AnMBR and advanced AnBEMR when treating the

609 pharmaceutical wastewater. They found microbial flora was negatively impacted (methane

610 yield below $0.16 \mathrm{~L} / \mathrm{g} \mathrm{COD}_{\text {removed }}\left(0.14 \mathrm{~L} \mathrm{CH}_{4}(\mathrm{STP}) / \mathrm{g} \mathrm{COD}_{\text {removed }}\right)$ was reported) in a

611 hypersaline scenario, which was due to the disrupted ordinary metabolic functions and

612 degradation kinetics with high salt concentrations. Jeison et al. [71] attributed the presence of 
613 very small sized and weak granules in both UASB and AnMBR systems to the high salinity

614 of the wastewater, despite the fact that membrane enhanced retention of active halotolerant 615 bacteria contributed to a superior sludge activity than UASB. They also revealed that the 616 long-term continuous adaption periods resulted in better levels of sodium tolerance, with the 617 observed $50 \%$ activity inhibitory concentration $\left(\mathrm{IC}_{50}\right)$ value for acetotrophic methanogenesis 618 at approximately $25 \mathrm{~g} \mathrm{Na}^{+} / \mathrm{L}$. In addition, high salinity as a consequence of salt accumulation 619 in the reactors is regarded as a significant concern for the AnOMBR in terms of fouling and 620 excess flux loss rather than inhibition or toxic effects on the biological processes [52,53].

621

622 3.4. Long chain fatty acids (LCFAs)

623

624 Long chain fatty acids (LCFAs), are potentially suitable substrates for biogas production.

625 However, the toxicity of LCFAs is known to impair granule formation, sludge flotation and 626 washout, suppress methanogenic activity, mass transfer limitations of substrate, nutrients and 627 biogas in anaerobic granular sludge bed reactors when treating high strength-lipid 628 wastewaters [10, 60, 72, 73]. Dereli et al. [72] assumed that the major drawbacks mentioned 629 above could be addressed by membrane assisted biomass retention in AnMBRs. However, 630 they found the AnMBR process still suffered from reversible LCFA inhibition at 50 days SRT 631 and in turn process instability, which was mainly caused by LCFA adsorption, although the 632 membrane guaranteed excellent biomass retention when treating lipid rich wastewaters. The 633 authors suggested AnMBR operation at shorter SRTs was preferred due to the deliberate 634 washout of adsorbed and free LCFA, thus reducing high concentration LCFA inhibition or 635 transport limitation. Nevertheless, a major fraction of LCFA would not remain degraded, 636 therefore lowering the biomethane potential. Dereli et al. concluded that sustainable methane 637 fermentation from all LCFAs required only very low applied Lipid/Mass ratios. Furthermore 638 they [73] observed LCFA inhibition at high SRTs in their lab-scale AnMBR system when 
639 treating wastewater with Fat, Oil, and Grease (FOG) concentration at $11.3 \pm 0.5 \mathrm{~g} / \mathrm{L}$. The 640 inhibitory effect accelerated biomass deflocculation and SMP release.

641 On the other hand the LCFA absorption on sludge flocs modified their hydrophobicity, 642 resulting in less fouling propensity. Jensen et al. [63] reported minor LCFA inhibition from an 643 AnMBR when treating slaughterhouse wastewater with average FOG concentration of 1407 $644 \mathrm{mg} / \mathrm{L}$. Ramos et al. [74] reported that the long-term sludge adaption to LCFAs was required 645 for high rate methanogenesis from LCFAs in an UASB coupled membrane system. 646 Acclimated sludge quickly reached maximum methane production from the digestion of 647 substrate with high oil and grease (O\&G) content (4.6-36 $\mathrm{g}$ O\&G/L) at OLR of $17 \mathrm{~kg}$ $648 \mathrm{COD} /\left(\mathrm{m}^{3} \mathrm{~d}\right)$, without any notable inhibitory effects. The advantages and disadvantages of 649 AnMBRs to mitigate problems induced by inhibitors are summarized in Table 3. 
Table 3 Advantages and disadvantages of AnMBRs for the mitigation of problems induced by inhibitors.

\begin{tabular}{lcl}
\hline Inhibitors & Inhibitory effects on biogas production \\
\hline Ammonia & - & Disrupting intracellular $\mathrm{pH}$ \\
& - & Increasing maintenance energy requirement \\
& - Inhibiting a specific enzyme reaction \\
- & Methanogenic activity loss \\
Sulfide & - The toxicity of hydrogen sulphide to anaerobes \\
& - The reduction on quality and quantity of biogas production \\
& - $\mathrm{H}_{2} \mathrm{~S}$ can cause corrosion in boilers, engines, and pipes causing \\
& higher maintenance and replacement costs \\
& - Downstream oxygen demand required for oxidising $\mathrm{H}_{2} \mathrm{~S}$
\end{tabular}

\section{Advantages/Disadvantages of AnMBRs}

- Complete retention of biomass

- Ammonia were filtered out with the permeate

- Acclimatisation and adaption of biomass to free ammonia due to the applied high SRT in AnMBRs

- Complete retention of slow-growing methanogens

- Higher methane production potential at higher temperature and higher SRT

- Sulfate content in the substrate significantly affected the overall operating cost.

- Promising for treating low/non sulphate-loaded wastewater

- Cost associated with membrane fouling

Salinity - Reduced methanogenic activity

- Biomass decay

- Long adaptation time

- Negative impact on granule stability and granule size.

- Enhanced retention of active halotolerant bacteria

- Flux decline due to salt accumulation

- Long term adaption leads to high tolerance

\section{LCFAs - Impairment of granulation}

- Sludge flotation, washout, and foam/scum accumulation

- LCFA precipitation on sludge particles

- Methanogenic inhibition due to mass transfer limitations

- No biomass washout

- Lesser fouling due to increased sludge hydrophobicity

- Inhibition due to floc deterioration and SMP release. 


\subsection{Temperature}

656

Temperature is a vital parameter that profoundly influences anaerobic processes. Attempts to produce biogas from AnMBRs have been made under all three different temperature ranges: psychrophilic $\left(0-20^{\circ} \mathrm{C}\right)[18,31]$, mesophilic $\left(20-42^{\circ} \mathrm{C}\right)[19,75]$ and thermophilic $\left(42-75^{\circ} \mathrm{C}\right)$ [76]. Thermophilic AnMBRs are known to have a rate-advantage over the others due to a faster reaction time and higher volumetric loading rate, thus demonstrating higher biogas productivity [2]. Both Liao et al. [12] and Lin et al. [29] investigated thermophilic SAnMBRs for biogas production from kraft evaporator condensate treatment at $55 \pm 1^{\circ} \mathrm{C}$, and proved that it was a feasible technology to produce a promising methane yield at average value of $0.35 \mathrm{~L}$

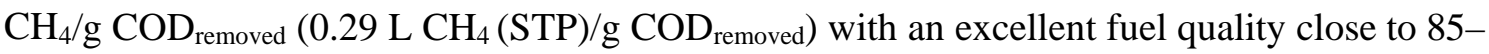
90\% methane in the biogas. They attributed higher methane yield to the higher sludge digestion rate making a larger contribution under thermophilic temperatures. Qiao et al. [76] also reported that producing methane from coffee grounds via the thermophilic co-digestion SAnMBR was feasible, and traceable hydrogen content of 100-200 ppm was found in the biogas. However, thermophilic AnMBRs are more sensitive to the presence of toxic

671 compounds such as hydrogen sulfide [12] and inhibitory substances in the feed, and

672 environmental changes. The thermophilic process's extreme temperature is also believed to 673 cause severe ammonia toxicity, digestion inhibition and unstable fermentation processes [3, 674 77].

675 Furthermore, higher membrane flux can be retained using lower energy requirements at 676 higher temperatures due to the reduced viscosity of the biomass suspension [10, 78]. 677 Membrane permeability can be further enhanced by decreasing the transmembrane pressure 678 (TMP) due to a lower permeate viscosity at high temperature. However, Jeison and van Lier 
679 [79] observed long-term fluxes in the thermophilic SAnMBR were in fact 2-3 times lower 680 than those attained under mesophilic conditions. Therefore, more studies regarding 681 temperature's effects on the sustainable flux are required so that biogas production from 682 AnMBRs is at its most efficient. Membrane fouling is another critical area of interest, which 683 impedes the development of thermophilic AnMBRs for biogas production. Lin et al. [29] 684 compared thermophilic and mesophilic AnMBRs at different OLRs but under similar 685 hydrodynamic conditions. A more compact, less porous cake layer with higher cake resistance 686 was observed in the thermophilic AnMBR, which was mainly due to the higher concentration 687 of fine particles and EPS release at higher temperatures. Furthermore, permeate from the 688 mesophilic AnMBR had much better quality than the thermophilic one. More attention should therefore be paid to the sustainable fouling mitigation measures in order to ensure the economic feasibility of thermophilic AnMBRs for biogas production.

Psychrophilic AnMBRs has recently attracted significant attention particularly in terms of generating biogas from low strength wastewaters [18]. It was found that both psychrophilic and mesophilic AnMBRs achieved comparable methane production rates [75, 80], although

694 the former corresponded to significant methane loss in the permeate $[75,81]$ and a slightly 695 higher fouling rate due to VFA accumulation $[18,75]$ and protein-dominated EPS release [82]. Last but not least, Gao et al. [83] reported temperature shocks led to a temporary increase in biogas generation rate, but shocks with larger magnitude at higher temperatures resulted in 698 performance being significantly disrupted. within the $\mathrm{pH}$ 6.5-8.5 range with the optimal range from 7.0 to 8.0 [3]. Such a $\mathrm{pH}$ range was usually maintained through neutralization, which requires the excessive use of chemicals such 
as sodium carbonate/biocarbonate or calcium carbonate since some streams have extreme $\mathrm{pH}$

706 values, and hydrolysis and acidogenesis phases will decrease $\mathrm{pH}$ values. Extreme $\mathrm{pH}$

707 conditions during AnMBRs operation can not only upset biological performance and methane

708 yield but also affect membrane permeability and lifespan [84]. Gao et al. [85] investigated the

709 effects of elevated $\mathrm{pH}$ shocks ( $\mathrm{pH}$ 8.0, 9.1 and 10.0) on biogas production from a SAnMBR,

710 and found that the $\mathrm{pH} 8.0$ shock had a minor impact, yet $\mathrm{pH} 9.1$ and 10.0 shocks did exert

711 significantly negative impacts on the methane yield. This was mainly due to the ammonia

712 toxicity and VFA accumulation at increased $\mathrm{pH}$ value. Serious membrane fouling resistance

713 was reported, due to $\mathrm{pH}$ shock induced sludge flocs breakage and the accumulation of fine

714 particles in the bulk sludge. In light of the difference in growth rates, and optimum $\mathrm{pH}$ for the

715 growth of acidogens (5.5-6.5) and methanogens (6.5-8.2), many researchers have worked on

716 phased AnMBRs, which separate acidogenesis and methanogenesis processes into the two-

717 stage reactor configuration [86]. Optimizing each stage separately in its own reactor reduces

718 VFA accumulation, facilitates process stability, and enhances the system's tolerance to

719 greater loading rate and toxicity. These features will lead to higher methane production. Such

720 a phased AnMBR has been successfully applied to high loading wastewaters treatment for

721 maximum methane yield [39, 86, 87].

722

723 4.3. Hydraulic retention time (HRT)

724

HRT is a key parameter from an economic perspective as it has a significant impact on the

726 capital cost, meaning shorter HRTs allow smaller biogas-producing AnMBRs [88]. Many

727 researchers have worked on the influence of HRT on biogas production from AnMBRs.

728 Generally, HRTs can range from as low as $2 \mathrm{~h}$ [33] to as high as $30 \mathrm{~d}$ [89] depending on feed

729 characteristics, system hydraulics, sludge properties, etc. Ho and Sung [90] reported that

730 methane recovery decreased by $13 \%$ from municipal wastewater as a result of the increased

Challenges in biogas production from anaerobic membrane bioreactors, Renewable Energy, 98, 120-134, 2016. 
731 COD accumulation in the AnMBR when reducing HRT from 12 to 6 hours. Therefore,

732 AnMBR operation with relatively long HRTs may maximize methane recovery. However,

733 Yuzir et al. [91] observed reduced methane productivity from AnMBRs with longer HRT due

734 to less COD available as substrate for methane production. Significantly enhanced methane

735 production was evident when high hydraulic shock load was applied (HRT $1 \mathrm{~d}$ ) and they

736 attributed this high yield to enhanced levels of hydrogenotrophic methanogenesis rather than

737 acetoclastic activity. Huang et al. [92] also reported that a shorter HRT increased biogas

738 production due to increased organic loading rate in a SAnMBR. However, too short an HRT

739 was not recommended due to higher biomass concentrations and higher SMP that could

740 worsen membrane fouling. Gao et al. [36] observed something different when they

741 investigated the effects of decreasing HRT on biogas production from an integrated anaerobic

742 fluidized-bed membrane bioreactor. They found that methane productivity increased when the

743 HRT decreased from $8 \mathrm{~h}$ to $6 \mathrm{~h}$, which was linked to the increased OLR. Meanwhile the

744 productivity decreased as more VFAs accumulated with a much shorter HRT.

$745 \quad$ HRT was controlled as an independent parameter from upflow velocity in the studies using

746 CSTR-AnMBRs as the main biological component. However, An et al. [93] reported that in

747 the UASB-AnMBRs without the recirculation, the impacts of HRT and upflow velocity could

748 be assessed dependently because they were inversely correlated to each other. They reported

749 that biogas yield almost doubled from 0.062 to $0.12 \mathrm{~L} / \mathrm{g} \mathrm{COD}$ removed $\left(0.057\right.$ to $0.11 \mathrm{~L} \mathrm{CH}_{4}$

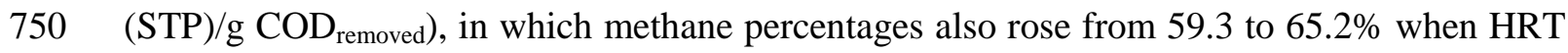

751 of a membrane coupled UASB reactor was gradually decreased from $10 \mathrm{~h}$ to $5.5 \mathrm{~h}$. They

752 attributed the enhanced gas production to the improved substrate distribution in the sludge

753 bed and enhanced mass transfer between biomass and substrate at a higher upflow velocity.

754 Based on the studies conducted by the researchers, it could be concluded optimized HRT

755 exists for each case depending on many factors such as feed characteristics, system hydraulics,

756 sludge properties, reactor design and configuration, substrate types, etc. Prolonged HRT may

Challenges in biogas production from anaerobic membrane bioreactors, Renewable Energy, 98, 120-134, 2016.36 
cause AnMBRs reactor volume to be used inadequately and shortened HRT may lead to VFA accumulation, reduced methane productivity and severe membrane fouling.

759

760

\subsection{Solid retention time (SRT)}

761

762

Unlike other types of anaerobic reactors, AnMBRs enable SRT to become completely

763

764

765

766

767

768

769

770

771

772

773

774

775

776

777

778

779

780

781

782 independent from HRT, irrespective of the sludge properties. SRT values ranged from $20 \mathrm{~d}$ [72,94] to infinite days [92], although most researchers worked using SRT values higher than 160 d. As a thumb of rule, AnMBRs operating at longer SRTs produce greater quantities of biogas because any decrease in the SRT may reduce the extent of reactions needed for stable digestion. For example, Huang et al. [92] in 2011 reported that a longer SRT would enhance the dominance of methanogenesis and lead to more biogas generation. In their study, methane yield rates of $0.670 \pm 0.203 \quad \mathrm{~L}^{\mathrm{C}} \mathrm{CH}_{4} / \mathrm{d}, \quad 0.906 \pm 0.357 \quad \mathrm{~L} \quad \mathrm{CH}_{4} / \mathrm{d}, \quad 1.290 \pm 0.267 \quad \mathrm{~L} \quad \mathrm{CH}_{4} / \mathrm{d}$ (0.610 $\left.\pm 0.203 \mathrm{~L} \mathrm{CH}_{4}(\mathrm{STP}) / \mathrm{d}, 0.825 \pm 0.357 \mathrm{~L} \mathrm{CH}_{4}(\mathrm{STP}) / \mathrm{d}, 1.175 \pm 0.267 \mathrm{~L} \mathrm{CH}_{4}(\mathrm{STP}) / \mathrm{d}\right)$ were reported at SRTs of 30, 60 and infinite days, respectively. Yeo and lee [95] suggested that AnMBR operation under a long SRT could permit low dissolved methane concentration in AnMBR permeate, along with high methane recovery. They attributed $45 \%$ more methane production at higher SRT to supplemental methane formation originating from biomass electrons via endogenous decay.

It is obvious long SRTs are more favorable in AnMBRs' operation since it results in minimal sludge production and hence significantly reduces disposal cost. However, longer SRTs operation can also impact on methanogenic activity due to a decrease in viable biomass concentration [10]. The effects of long SRTs on membrane fouling, furthermore, require urgent attention. Prolonged SRTs can hinder sludge flocculation and reduce particle size, and increase the release of soluble microbial products (SMP) [92]. On the other hand, high sludge concentration at high SRT can result in a rapid cake formation and compaction, leading to 
783

784

785

786

787

788

789

790

791

792

793

794

795

796

797

798

799

800

801

802

803

804

805

806

807

808

excess flux decline [10]. Additionally, the accumulation of inorganic solids at high SRTs may also increase inorganic fouling, which in many studies was found to be serious [73, 96].

\subsection{Organic loading rate (OLR)}

AnMBR processes have the competitive advantage of accommodating fluctuations in the organic loading, and OLRs ranging from 0.23 [37] to $33.7 \mathrm{~kg} \mathrm{COD} / \mathrm{m}^{3} \cdot \mathrm{d}$ [76] have been applied in AnMBRs for biogas production. In general, OLR represents the quantity of volatile solids fed into a biogas digester per day under continuous operation [2]. When an increase in OLR occurs, therefore, the biogas yield is supposed to also increase to a certain extent. An et al. [93] reported that biogas yield from an AnMBR rose linearly with an increase in the organic loading. Wijekoon et al. [97] also observed a continuous increase in biogas production rate from $5 \mathrm{~L} / \mathrm{d}$ to $35 \mathrm{~L} / \mathrm{d}$ with increasing loading rate from 5 to $12 \mathrm{~kg} \mathrm{COD} / \mathrm{m}^{3} \cdot \mathrm{d}$ in a two-stage thermophilic AnMBR. Bornare et al. [16] reported an increase in the average biogas generation from 159 to $289 \mathrm{~L} / \mathrm{d}$ but a decrease in the biogas yield from 0.48 to $0.42 \mathrm{~L}$

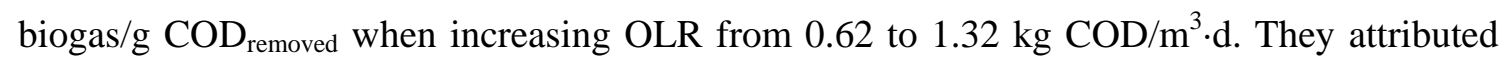
this conflicting outcome to a better food-to-microorganisms $(\mathrm{F} / \mathrm{M})$ ratio $(0.08 \mathrm{~kg} \mathrm{COD} / \mathrm{kg}$ MLVSS/day) at a lower OLR. Dereli et al. [10], however, stated that the effect of OLR should be assessed together with SRT and biomass activity as the system's OLR was not an independent parameter.

Applied temperature also exerts a profound influence on the applicable OLRs in AnMBRs.

Thermophilic AnMBRs emerge as being more effective in coping with higher volumetric loading than AnMBRs operating in the mesophilic range [98]. It should be also noted that as the organic loading rate increases, the risk of deteriorating biogas production due to VFA accumulation may occur due to the inhibition of microbial activity [97]. For example, Saddoud and Sayadi [39] documented a process failure in their study, i.e. a drastic decrease in 
809 the methane yield at OLR of $16.3 \mathrm{~kg} \mathrm{COD} / \mathrm{m}^{3} \cdot \mathrm{d}$ due to VFA accumulation and methanogenic

810 inhibition in a one-phase AnMBR. They subsequently suggested a two-stage AnMBR with

811 the anaerobic filter as acidogenic reactor and jet flow AnMBR as methanogenic reactor at

812 high OLR and achieved a significant improvement in biogas conversion in the staged

813 AnMBR.

814 Serious fouling caused by the release of EPS/SMP and the accumulation of large fine 815 particles, became another issue associated with high loading AnMBRs when using AnMBRs

816 for biogas production [99]. In the face of the comprehensive effects of OLR on methane

817 production, Wei et al. [19] proposed the concept of sustainable OLR to optimize energy

818 recovery potential from typical municipal wastewater through mesophilic AnMBRs. They

819 reported sustainable OLR of $6 \mathrm{~kg} \mathrm{COD} / \mathrm{m}^{3} \cdot \mathrm{d}$ could result in maximum methane yield up to a

820 theoretical value of $0.382 \mathrm{~L} \mathrm{CH}_{4} / \mathrm{g} \mathrm{COD}_{\text {removed }}\left(0.318 \mathrm{~L} \mathrm{CH}_{4}(\mathrm{STP}) / \mathrm{g} \mathrm{COD}_{\text {removed }}\right.$ ). Table 4

821 summarizes the operational factors affecting biogas production from AnMBRs and the 822 recommendations for optimized biogas production.

823 
Table 4 The effects of operational factors on biogas production from AnMBRs and possible suggestions for optimized biogas production

\section{Factors The effects on biogas production process}

\section{Thermophilic:}

- Faster reaction rates $\rightarrow$ higher-load bearing capacity $\rightarrow$ higher biogas productivity

Temperature

- Possible acidification $\rightarrow$ inhibition of biogas production

- Decreased stability and increased toxicity $\rightarrow$ poor methanogensis $\rightarrow$ higher net energy input and larger investments

- Difficulty in anaerobic biomass immobilization $\rightarrow$ poor sludge settling characteristics $\rightarrow$ reduced methanogenic activities $\rightarrow$ poor effluent quality

- Less cooling required $\rightarrow$ improved process economics

- Sludge decay with non-adapted mesophilic sludge $\rightarrow$ serious membrane fouling

- Reduced sludge viscosity $\rightarrow$ A higher flux $\rightarrow$ process efficiency

$$
\rightarrow \text { Lower shear rates } \rightarrow \text { lower energy requirement }
$$

- A lower permeate viscosity $\rightarrow$ increased membrane permeability by decreasing TMP

- More compact cake layer $\rightarrow$ higher cake layer resistance $\rightarrow$ server fouling issues $\rightarrow$ very low long-term flux $\rightarrow$ process inefficiency

Mesophilic:

- Better process stability, higher biomass richness, better permeate quality but possible low methane yields and poor biodegradability and nutrient imbalance

Psychrophilic:

- Enhanced methane solubility $\rightarrow$ loss of methane in effluent $\rightarrow$ lower methane recovery

- TSS and soluble COD accumulation and a higher viscosity $\rightarrow$ increased filtration resistance $\rightarrow$ increased fouling and operational cost

- Enhanced membrane removal and compensation for the decreased SMA and bulk sludge removal

- Energy requirement for operating the system is lower

- Reduced reaction and hydrolysis rates $\rightarrow$ reduced methanogenic activity

\section{Possible suggestions for optimized biogas} production from AnMBRs

- Two phase AnMBRs with thermophilic hydrolysis/acidogenesis and mesophilic methanogenesis

- Avoidance of drastic temperature changes 
Temperature changes:

- Temperature decrease $\rightarrow$ decreases in the VFA production rate, the ammonia concentration, the substrate utilization rate and the metabolic rate of the microorganisms $\rightarrow$ increased start-up times $\rightarrow$ decreasing $\mathrm{CH}_{4}$ and $\mathrm{H}_{2}$ yields

- Temperature increase $\rightarrow$ increase in $\mathrm{pH}$, hydrolysis of organic particulates $\rightarrow$ increase in methane potential

- Temperature increase $\rightarrow$ Free ammonia concentration $\rightarrow$ methanogenic inhibition

- Temperature fluctuation $\rightarrow$ stress on biomass $\rightarrow$ increase membrane fouling and operational cost

- Extremely low pH value $\rightarrow$ acidification and VFA accumulation $\rightarrow$ reduced methane yield

- Extremely high pH value $\rightarrow$ increased ammonia toxicity and VFA inhibition $\rightarrow$ reduced methane yield

- $\mathrm{pH}$ shocks $\rightarrow$ dispersion of sludge flocs $\rightarrow$ the accumulation of colloids, solutes or biopolymers in the bulk sludge suspension $\rightarrow$ deteriorated membrane performance and biogas production potential
- Optimum HRT exists, which ensures the maximum methane productivity

- HRT lower than the optimal value $\rightarrow$ VFA accumulation $\rightarrow$ reduced methane yield $\rightarrow$ server fouling

- HRT above the optimal value $\rightarrow$ insufficient utilization of biogas digester component $\rightarrow$ reduced methane production

- Long SRT $\rightarrow$ enhance dominancy of methanogenesis $\rightarrow$ enhanced methane yield

- Long SRT $\rightarrow$ reduced dissolved methane $\rightarrow$ higher methane recovery

- Long SRT $\rightarrow$ reduced sludge disposal and cost

- Long SRT $\rightarrow$ reduced sludge particle size and release of SMP $\rightarrow$ membrane fouling

- Long SRT $\rightarrow$ cake formation and consolidation $\rightarrow$ increased fouling cost

- Long SRT $\rightarrow$ accumulation of inorganic solids $\rightarrow$ inorganic fouling
- Two phase AnMBR with optimized conditions for both acidogenic and methanogenic reactor to bring biogas yield optimization

- Minimize $\mathrm{pH}$ shock loading by neutralizing the feed with chemicals such as sodium biocarbonate

- Avoid operation at too high or too low a HRT

- Operate AnMBRs for maximum biogas production at optimal HRT

- Long SRT is generally recommended for AnMBRs operation

- Additional care is required for fouling mitigation at long SRT 
- Increased OLR $\rightarrow$ higher metabolic activity of methanogens $\rightarrow$ increase biogas yield and methane content in the biogas to certain extent

- High OLR $\rightarrow$ VFA accumulation $\rightarrow$ irreversible acidification $\rightarrow$ risk of a deteriorated biogas yield

- High OLR or organic shock loading $\rightarrow$ release of tight EPS/SMP and accumulation of fine particles $\rightarrow$ serious membrane fouling
- Operating AnMBR at sustainable OLR to maximize the methane yield.

- Thermophilic systems and effluent recirculation can help relieve systems from the overloading issues 


\section{Future perspectives}

The critical analysis of recent literature reveals that much progress has been made in the research and development of AnMBRs for biogas production. The green perspectives of AnMBRs including biogas production, high effluent quality, waste minimization, high capacity, footprint efficiency (reducing capital costs), lower energy requirements, and decentralized operation, mean that such a technology can produce bioenergy through a sustainable bioprocess. For example, a substantial commercial value of US\$341640/year could be obtained from a full-scale AnMBR's recovery of biogas [17]. Most research on AnMBRs has focused on investigating traditional configurations such as CSTR, UASB, AFBR, etc. Recent advances in the modification of conventional AnMBRs and the development of novel AnMBR processes have witnessed greater outcomes. Incorporating a dynamic membrane into AnMBRs significantly reduced capital exploitation costs for the membrane and its cleaning and replacement. Thermally-driven membrane distillation minimized the methane loss through the liquid phase and completely rejected total phosphorus when coupled with AnMBRs. The forward osmosis process in the AnOMBR provides nearly complete removal of total phosphorous and records a relatively good rejection rate for total nitrogen and ammonia [52, 53]. The developments of V-AnMBRs, Gl-AnMBRs, AnBEMRs and AnSMBRs offer new insights into sustainable fouling mitigation strategies that enhance the economic feasibility of AnMBRs for biogas production. The literature review revealed that most of the research reported on biogas production from AnMBRs was confined to lab scale experiment. The results from lab testing most often could not directly transfer to industrial and commercial practical application. Fundamental information regarding the energy consumption of each specific AnMBR and its capital cost for installation and operation is still lacking. Further research at well controlled pilot or full scale AnMBRs studies is greatly appreciated to obtain valuable data, in order to support the wide 
implementation of such green technology at industrial scale.

Depending on the origin, the feedstock for AnMBRs may contain inhibitory compounds such as ammonia, sulfide, salt or LCFAs. Accumulation of these inhibitors in AnMBR may cause process upset or even reactor failure, indicated by the reduction in daily biogas production and methane composition. Therefore, co-digestion with other wastes, acclimatization of microorganisms to toxic compounds, and pretreatment to remove or counteract toxicants can enhance the process stability and optimize biogas production [60]. Despite extensive research on the operational parameters' effects on the biogas productivity from AnMBRs, a universal operational protocol has not yet been developed to optimize biogas production due to the complexity for the consortia of microorganisms, variations in the feed characteristics, and differences in system hydraulics. Although thermophilic AnMBRs have a rate-advantage over mesophilic ones, greater investment is required to deploy thermophilic systems and mitigate the severe membrane fouling.

Prolonged SRT is believed to minimize the toxic impacts and enhance methanogensis but the resultant fouling issues and subsequent flux decline are problems that remain unsolved. Decreasing the HRT to acquire the optimal OLR is a possibility. However, published information on the maximum sustainable loading rate is still lacking and its relationship to the applied HRT requires further investigation. Numerous researchers have reported the issues associated with dissolved methane at the effluent, despite variations in AnMBR configurations. Due to economic and environmental concerns, methane leakages must be minimized [75]. Developing effective and applicable dissolved methane recovery process is of great interest to optimize bioenergy recovery and minimize direct greenhouse gas emissions to the atmosphere.

\section{Conclusions}


AnMBR technology, as future green bioprocess has much potential for renewable energy production. Currently AnMBRs are starting to evolve to the next level. Advanced AnMBRs have attracted a lot of interest in producing high fuel quality biogas when they are combined with many novel technologies such as Anammox, dynamic membrane, membrane distillation, etc. The biogas production from AnMBRs is greatly influenced by many factors including temperature, $\mathrm{pH}$, HRT, SRT, and other variables. The opportunity to apply such green technology on a commercial scale first needs prospective research studies to overcome many challenges such as methane recovery, product inhibition, membrane fouling, and membrane cost.

\section{Acknowledgements}

The authors are grateful for the support of Centre for Technology in Water and Wastewater (CTWW), UTS and Australian Postgraduate Award.

\section{References}

[1] Deublein D, Steinhauser A. Biogas from Waste and Renewable Resources: An Introduction. Wiley-VCH, Weinheim; 2008, p. 10.

[2] Mao CL, Feng YZ, Wang XJ, Ren GX. Review on research achievements of biogas from anaerobic digestion. Renew. Sust. Energy Rev. 2015; 45:540-555.

[3] Weiland P. Biogas production: current state and perspectives. Appl. Microbiol Biotechnol. 2010; 85:849-860.

[4] He Y, Bagley DM, Leung KT, Liss SN, Liao BQ. Recent advances in membrane technologies for biorefining and bioenergy production. Biotechnol Adv. 2012; 30:817858. 
[5] Appels L, Lauwers J, Degréve J, Helsen L, Lievens B, Willems K, Impe JV, Dewil R. Anaerobic digestion in global bio-energy production: Potential and research challenges. Renew. Sust. Energy Rev. 2011; 15:4295-4301.

[6] Ylitervo P, Akinbomia J, Taherzadeha MJ. Membrane bioreactors' potential for ethanol and biogas production: a review. Environ. Technol. 2013; 34(13-14): 17111723.

[7] Visvanathan C, Abeynayaka A. Developments and future potentials of anaerobic membrane bioreactors (AnMBRs). Membrane Water Treatment 2012; 3(1): 1-23.

[8] Angelidaki I, Ellegaard L, Ahring BK. A mathematical model for dynamic simulation of anaerobic digestion of complex substrates: focusing on ammonia inhibition. Biotechnol. Bioeng. 1993; 42:159-166.

[9] McCarty PL, Smith DP. Anaerobic wastewater treatment. Environ. Sci. Technol. 1986; 20:1200-1226.

[10] Dereli RK, Ersahin ME, Ozgun H, Ozturk I, Jeison D, van der Zee FP, van Lier JB. Potentials of anaerobic membrane bioreactors to overcome treatment limitations induced by industrial wastewaters. Bioresour. Technol. 2012; 122:160-170.

[11] Wang AJ, Li WW, Yu HQ. Advances in biogas technology. Adv. Biochem. Eng. Biotechnol. 2012; 128:119-141.

[12] Liao BQ, Xie K, Lin HJ, Bertoldo D. Treatment of kraft evaporator condensate using a thermophilic submerged anaerobic membrane bioreactor. Water Sci. Technol. 2010; 61:2177-2183.

[13] Minardi ER, Chakraborty S, Calabrò V, Curcio S, Drioli E. Membrane applications for biogas production and purification processes: an overview on a smart alternative for process intensification. RSC Adv. 2015; 5:14156-14186. 
[14] Ozgun H, Dereli RK, Ersahin ME, Kinaci C, Spanjers H, van Lier JB. A review of anaerobic membrane bioreactors for municipal wastewater treatment: Integration options, limitations and expectations. Sep. Purif. Technol. 2013; 118:89-104.

[15] Liao BQ, Kraemer JT, Bagley DM. Anaerobic membrane bioreactors: Applications and research directions. Crit. Rev. Env. Sci. Technol. 2006; 36:489-530.

[16] Bornare J, Kalyyanraman V, Sonde RR. Chapter 10-Application of Anaerobic Membrane Bioreactor (AnMBR) for Low-Strength Wastewater Treatment and Energy Generation. Industrial Wastewater Treatment, Recycling and Reuse; 2014, p. 399-434.

[17] Lin HJ, Chen JR, Wang FY, Ding LX, Hong HC. Feasibility evaluation of submerged anaerobic membrane bioreactor for municipal secondary wastewater treatment. Desalination 2011; 280:120-126.

[18] Martinez-Sosa D, Helmreich B, Horn H. Anaerobic submerged membrane bioreactor (AnMBR) treating low-strength wastewater under psychrophilic temperature conditions. Process Biochem. 2012; 47:792-798.

[19] Wei CH, Harb M, Amy G, Hong PY, Leiknes T. Sustainable organic loading rate and energy recovery potential of mesophilic anaerobic membrane bioreactor for municipal wastewater treatment. Bioresour. Technol. 2014; 166:326-334.

[20] Jung KW, Kim DH, Kim SH, Shin HS. Bioreactor design for continuous dark fermentative hydrogen production. Bioresour. Technol. 2011; 102:8612-8620.

[21] Lee DY, Li YY, Oh YK, Kim MS, Noike T. Effect of iron concentration on continuous $\mathrm{H}_{2}$ production using membrane bioreactor. Int. J. Hydrogen Energy 2009; 34:1244-52.

[22] Shen L, Bagley DM, Liss SN. Effect of organic loading rate on fermentative hydrogen production from continuous stirred tank and membrane bioreactors. Int. J. Hydrogen Energy 2009; 34:3689-3696. 
[23] Lee DY, Li YY, Noike T, Cha GC. Behavior of extracellular polymers and bio-fouling during hydrogen fermentation with a membrane bioreactor. J. Membr. Sci. 2008; 322:13-18.

[24] Lee KS, Lin PJ, Fangchiang K, Chang JS. Continuous hydrogen production by anaerobic mixed microflora using a hollow-fiber microfiltration membrane bioreactor. Int. J. Hydrogen Energy 2007; 32:950-957.

[25] Brockmann M, Seyfried CF. Sludge activity under the conditions of crossflow microfiltration. Water Sci. Technol. 1997; 35:173-181.

[26] Garcia IM, Mokosch M, Soares A, Pidou M, Jefferson B. Impact of reactor configuration on the performance of anaerobic MBRs: Treatment of settled sewage in temperature climates. Water Res. 2013; 47:4853-4860.

[27] van Voorthuizen E, Zwijnenburg A, van der Meer W, Temmink H. Biological black water treatment combined with membrane separation. Water Res. 2008; 42(16): 43344340.

[28] Xie K, Lin HJ, Mahendran B, Bagley DM, Leung KT, Liss SN, Liao BQ. Performance and fouling characteristics of a submerged anaerobic membrane bioreactor for kraft evaporator condensate treatment. Environ. Technol. 2010; 31(5), 511-521.

[29] Lin HJ, Xie K, Mahendran B, Bagley DM, Leung KT, Liss SN, Liao BQ. Sludge properties and their effects on membrane fouling in submerged anaerobic membrane bioreactors (SAnMBRs). Water Res. 2009; 43:3827-3837.

[30] Wen C, Huang X, Qian Y. Domestic wastewater treatment using an anaerobic bioreactor coupled with membrane filtration. Process Biochem. 1999; 35:335-340.

[31] Chu LB, Yang FL, Zhang XW. Anaerobic treatment of domestic wastewater in a membrane-coupled expanded granular sludge bed (EGSB) reactor under moderate to low temperature. Process Biochem. 2005; 40(3-4):1063-70. 
[32] Shin C, McCarty PL, Kim J, Bae J. Pilot-scale temperate-climate treatment of domestic wastewater with a staged anaerobic fluidized membrane bioreactor (SAFMBR). Bioresour. Technol. 2014; 159:95-103.

[33] Kim JH, Kim KH, Ye HY, Lee EY, Shin JH, McCarty PL, Bae JH. Anaerobic fluidized bed membrane bioreactor for wastewater treatment. Environ. Sci. Technol. 2011; 45:576-581.

[34] Yoo R, Kim J, McCarty PL, Bae J. Anaerobic treatment of municipal wastewater with a staged anaerobic fluidized membrane bioreactor (SAF-MBR) system. Bioresour. Technol. 2012; 120:133-139.

[35] Dutta K, Lee MY, Lai WW, Lee CH, Lin AY, Lin CF, Lin JG. Removal of pharmaceuticals and organic matter from municipal wastewater using two-stage anaerobic fluidized membrane bioreactor. Bioresour. Technol. 2014; 165: 42-49.

[36] Gao DW, Gao DW, Hu Q, Yao C, Ren NQ, Wu WM. Integrated anaerobic fluidizedbed membrane bioreactor for domestic wastewater treatment. Chem. Eng. J. 2014b; 240:362-368.

[37] Saddoud A, Ellouze M, Dhouib A, Sayadi S. Anaerobic membrane bioreactor treatment of domestic wastewater in Tunisia. Desalination 2007a; 207:205-215.

[38] Saddoud A, Abdelkafi S, Sayadi S. Effects of domestic wastewater toxicity on anaerobic membrane-bioreactor (MBR) performances. Environ. Technol. 2009; 30:1361-1369.

[39] Saddoud A, Sayadi S. Application of acidogenic fixed-bed reactor prior to anaerobic membrane bioreactor for sustainable slaughterhouse wastewater treatment. J. Hazard. Mater. 2007; 149:700-706.

[40] Li ZY, Xu XD, Xu XC, Yang FL, Zhang SS. Sustainable operation of submerged Anammox membrane bioreactor with recycling biogas sparging for alleviating membrane fouling. Chemosphere 2015b; 140:106-113. 
[41] Suneethi S, Joseph K. ANAMMOX process start up and stabilization with an anaerobic seed in Anaerobic Membrane Bioreactor (AnMBR). Bioresour. Technol. 2011; 102, 8860-8867.

[42] Dai WC, Xu XC, Liu B, Yang FL. Toward energy-neutral wastewater treatment: A membrane combined process of anaerobic digestion and nitritation-anammox for biogas recovery and nitrogen removal. Chem. Eng. J. 2015; 279:725-734.

[43] Ersahin ME, Ozgun H, Tao Y, van Lier JB. Applicability of dynamic membrane technology in anaerobic membrane bioreactors. Water Res. 2014; 48, 420-429.

[44] Ma JX, Wang ZW, Zou XX, Feng JJ, Wu ZC. Microbial communities in an anaerobic dynamic membrane bioreactor (AnDMBR) for municipal wastewater treatment: Comparison of bulk sludge and cake layer. Process Biochem. 2013; 48:510-516.

[45] Ersahin ME, Ozgun H, Dereli PK, Ozturk I, Roest K, van Lier JB. A review on dynamic membrane filtration: Materials, applications and future perspectives. Bioresour. Technol. 2012; 122: 196-206.

[46] Alibardi L, Cossu R, Saleem M, Spagni A. Development and permeability of a dynamic membrane for anaerobic wastewater treatment. Bioresour. Technol. 2014; $161: 236-244$.

[47] Xie ZF, Wang ZW, Wang QY, Zhu CW, Wu ZC. An anaerobic dynamic membrane bioreactor (AnDMBR) for landfill leachate treatment: Performance and microbial community identification. Bioresour. Technol. 2014; 161:29-39.

[48] Goh S, Zhang JS, Liu Y, Fane AG. Membrane Distillation Bioreactor (MDBR) - A lower Green-House-Gas (GHG) option for industrial wastewater reclamation. Membrane Distillation Bioreactor (MDBR) - A lower Green-House-Gas (GHG) option for industrial wastewater reclamation. Chemosphere 2015; 140:129-142. 
[49] Kim HC, Shin J, Won S, Lee JY, Maeng SK, Song KG. Membrane distillation combined with an anaerobic moving bed biofilm reactor for treating municipal wastewater. Water Res. 2015; 71:97-106.

[50] Phattaranawik J, Fane AG, Pasquier ACS, Bing W. A novel membrane bioreactor based on membrane distillation. Desalination 2008; 223:386-395.

[51] Smith AL, Stadler LB, Love NG, Skerlos SJ, Raskin L. Perspectives on anaerobic membrane bioreactor treatment of domestic wastewater: a critical review. Bioresour. Technol. 2012; 122:149-159.

[52] Gu YS, Chen L, Ng JW, Lee S, Chang VW, Tang CY. Development of anaerobic osmotic membrane bioreactor for low-strength wastewater treatment at mesophilic condition. J. Membr. Sci. 2015; 490:197-208.

[53] Chen L, Gu YS, Cao CQ, Zhang J, Ng JW, Tang CY. Performance of a submerged anaerobic membrane bioreactor with forward osmosis membrane for low-strength wastewater treatment. Water Res. 2014; 50:114-123.

[54] Kim J, Shin J, Kim H, Lee JY, Yoon M, Won S, Lee BC, Song KG. Membrane fouling control using a rotary disk in a submerged anaerobic membrane sponge bioreactor. Bioresour. Technol. 2014; 172:321-327.

[55] Gimenez JB, Marti N, Ferrer J, Seco A. Methane recovery efficiency in a submerged anaerobic membrane bioreactor (SAnMBR) treating sulphate-rich urban wastewater: Evaluation of methane losses with the effluent. Bioresour. Technol. 2012; 118:67-72.

[56] Prieto AL, Futselaar H, Lens PNL, Bair R, Yeh DH. Development and start up of a gas-lift anaerobic membrane bioreactor (Gl-AnMBR) for conversion of sewage to energy, water and nutrients. J. Membrane Sci. 2013; 441:158-167.

[57] Vrieze JD, Hennebel T, Van den Brande J, Bilad RM, Bruton TA, Vankelecom IFJ, Verstraete W, Boon N. Anaerobic digestion of molasses by means of a vibrating and 
non-vibrating submerged anaerobic membrane bioreactor. Biomass and bioenergy 2014; 68:95-105.

[58] Kola A, Ye Y, Le-Clech P, Chen V. Transverse vibration as novel membrane fouling mitigation strategy in anaerobic membrane bioreactor applications. J. Membrane Sci. 2014; 455:320-329.

[59] Ng KK, Shi XQ, Tang M, Ng HY. A novel application of anaerobic bio-entrapped membrane reactor for the treatment of chemical synthesis-based pharmaceutical wastewater. Sep. Purif. Technol. 2014; 132:71-78.

[60] Chen Y, Cheng JJ, Creamer KS. Inhibition of anaerobic digestion process: A review. Bioresour. Technol. 2008; 99:4044-4064.

[61] Kanai M, Ferre V, Wakahara S, Yamamoto T, Moro M. A novel combination of methane fermentation and MBR - Kubota Submerged Anaerobic Membrane Bioreactor process. Desalination 2010; 250:964-967.

[62] Meabe E, Deleris S, Soroa S, Sancho L. Performance of anaerobic membrane bioreactor for sewage sludge treatment: Mesophilic and thermophilic processes. J. Membr. Sci. 2013; 446:26-33.

[63] Jensen PD, Yap SD, Boyle-Gotla A, Janoschka J, Carney C, Pidou M, Batstone, DJ. Anaerobic membrane bioreactors enable high rate treatment of slaughterhouse wastewater. Biochem. Eng. J. 2015; 97:132-141.

[64] Koster IW, Lettinga G. The influence of ammonium-nitrogen on the specific activity of pelletized methanogenic sludge. Agric. Wastes 1984; 9:205-216.

[65] Ferrer J, Pretel R, Durán F, Giménez JB, Robles A, Ruano MV, Serralta J, Ribes J, Seco A. Design methodology for submerged anaerobic membrane bioreactors (AnMBR): A case study. Sep. Purif. Technol. 2015; 141:378-386. 
[66] Pretel R, Robles A, Ruano MV, Seco A, Ferrer J. The operating cost of an anaerobic membrane bioreactor (AnMBR) treating sulphate-rich urban wastewater. Sep. Purif. Technol. 2014; 126:30-38.

[67] Giménez JB, Robles A, Carretero L, Durán F, Ruano MV, Gatti MN, Ribes J, Ferrer J, Seco A. Experimental study of the anaerobic urban wastewater treatment in a submerged hollow-fibre membrane bioreactor at pilot scale. Bioresour. Technol. 2011; 102:8799-8806.

[68] Rinzema A, Lettinga G. The effect of sulphide on the anaerobic degradation of propionate. Environ. Technol. 1988; 9(2):83-88.

[69] Speece RE. Anaerobic biotechnology for industrial wastewater treatment. Environ. Sci. Technol. 1983; 17 (9):416-427.

[70] Li Q, Li YY, Qiao W, Wang XC, Takayanagi K. Sulfate addition as an effective method to improve methane fermentation performance and propionate degradation in thermophilic anaerobic co-digestion of coffee grounds, milk and waste activated sludge with AnMBR. Bioresour. Technol. 2015a; 185:308-315.

[71] Jeison D, Kremer B, van Lier JB. Application of membrane enhanced biomass retention to the anaerobic treatment of acidified wastewaters under extreme saline conditions. Sep. Purif. Technol. 2008; 64:198-205.

[72] Dereli RK, van der Zee FP, Heffernan B, Grelot A, van Lier JB. Effect of sludge retention time on the biological performance of anaerobic membrane bioreactors treating corn-to-ethanol thin stillage with high lipid content. Water Res. 2014b; 49:453-464.

[73] Dereli RK, Heffernan B, Grelot A, van der Zee FP, van Lier JB. Influence of high lipid containing wastewater on filtration performance and fouling in AnMBRs operated at different solids retention times. Sep. Purif. Technol. 2015; 139:43-52. 
[74] Ramos C, Garcia A, Diez V. Performance of an AnMBR pilot plant treating highstrength lipid wastewater: Biological and filtration processes. Water Res. 2014; 67, 203-215.

[75] Martinez-Sosa D, Helmreich B, Netter T, Paris S, Bischof F. Anaerobic submerged membrane bioreactor (AnMBR) for municipal wastewater treatment under mesophilic and psychrophilic temperature conditions. Bioresour. Technol. 2011; 102:1037710385.

[76] Qiao W, Takayanagi K, Niu QG, Shofie M, Li YY. Long-term stability of thermophilic co-digestion submerged anaerobic membrane reactor encountering high organic loading rate, persistent propionate and detectable hydrogen in biogas. Bioresour. Technol. 2013; 149:92-102.

[77] Angelidaki I, Ahring BK. Thermophilic anaerobic digestion of livestock waste: the effect of ammonia. Appl. Microbiol. Biotechnol. 1994; 38(4):560-564.

[78] Jeison D, van Lier JB. Cake layer formation in anaerobic submerged membrane bioreactors (AnSMBR) for wastewater treatment. J. Membrane Sci. 2006b; 284:227236.

[79] Jeison D, van Lier JB. On-line cake-layer management by trans-membrane pressure steady state assessment in anaerobic membrane bioreactors for wastewater treatment. Biochem. Eng. J. 2006a; 29(3):204-209.

[80] Trzcinski AP, Stuckey D. Treatment of municipal solid waste leachate using a submerged anaerobic membrane bioreactor at mesophilic and psychrophilic temperatures: Analysis of recalcitrants in the permeate using GC-MS. Water Res. 2010; 44:671-680.

[81] Smith AL, Skerlos SJ, Raskin L. Psychrophilic anaerobic membrane bioreactor treatment of domestic wastewater. Water Res. 2013; 47:1655-1665. 
[82] Gao DW, Hu Q, Yao C, Ren NQ. Treatment of domestic wastewater by an integrated anaerobic fluidized-bed membrane bioreactor under moderate to low temperature conditions. Bioresour. Technol. 2014a, 159, 193-198.

[83] Gao WJ, Leung KT, Qin WS, Liao BQ. Effects of temperature and temperature shock on the performance and microbial community structure of a submerged anaerobic membrane bioreactor. Bioresour. Technol. 2011; 102:8733-8740.

[84] Lin HJ, Peng W, Zhang MJ, Chen JR, Hong HC, Zhang Y. A review on anaerobic membrane bioreactors: Applications, membrane fouling and future perspectives. Desalination 2013; 314:169-188.

[85] Gao WJ, Lin HJ, Leung KT, Liao BQ. Influence of elevated $\mathrm{pH}$ shocks on the performance of a submerged anaerobic membrane bioreactor. Process Biochem. 2010; 45:1279-1287.

[86] Chaikasem S, Jacob P, Visvanathan C. Performance improvement in a two- stage thermophilic anaerobic membrane bioreactor using PVA-gel as biocarrier. Desalin. Water. Treat. 2015; 53(10):2839-2849.

[87] Saddoud A, Hassairi I, Sayadi S. Anaerobic membrane reactor with phase separation for the treatment of cheese whey. Bioresour. Technol. 2007b; 98(11):2102-2108.

[88] Stuckey DC. Recent developments in anaerobic membrane reactors. Bioresour. Technol. 2012; 122:137-148.

[89] Jeong E, Kim HW, Nam JY, Shin HS. Enhancement of bioenergy production and effluent quality by integrating optimized acidification with submerged anaerobic membrane bioreactor. Bioresour. Technol. 2010; 101:7-12.

[90] Ho J, Sung S. Anaerobic Membrane Bioreactor Treatment of Synthetic Municipal Wastewater at Ambient Temperature. Water Environ Res. 2009; 81(9):922-928. 
[91] Yuzir A, Chelliapan S, Sallis PJ. Influence of step increases in hydraulic retention time on (RS)-MCPP degradation using an anaerobic membrane bioreactor. Bioresour. Technol. 2011; 102:9456-9461.

[92] Huang Z, Ong SL, Ng HY. Submerged anaerobic membrane bioreactor for lowstrength wastewater treatment: effect of HRT and SRT on treatment performance and membrane fouling. Water Res. 2011; 45:705-713.

[93] An YY, Yang FL, Bucciali B, Wong FS. Municipal wastewater treatment using a UASB coupled with cross-flow membrane filtration. J. Environ. Eng. 2009; 135:8691.

[94] Dereli RK, Grelot A, Heffernan B, van der Zee FP, van Lier JB. Implications of changes in solids retention time on long term evolution of sludge filterability in anaerobic membrane bioreactors treating high strength industrial wastewater. Water Res. 2014a; 59:11-22.

[95] Yeo H, Lee HS. The effect of solids retention time on dissolved methane concentration in anaerobic membrane bioreactors. Environ. Technol. 2013; 34(1314):2105-2112.

[96] Kang IJ, Yoon SH, Lee CH. Comparison of the filtration characteristics of organic and inorganic membranes in a membrane-coupled anaerobic bioreactor. Water Res. 2002; 36:1803-1813.

[97] Wijekoon KC, Visvanathan C, Abeynayaka A. Effect of organic loading rate on VFA production, organic matter removal and microbial activity of a two-stage thermophilic anaerobic membrane bioreactor. Bioresour. Technol. 2011; 102:5353-5360.

[98] Skouteris G, Hermosilla D, Patricio L, Negro C, Blanco A. Anaerobic membrane bioreactors for wastewater treatment: A review. Chem. Eng. J. 2012; 198-199:138148. 
[99] Liu Y, Liu HN, Cui L, Zhang KS, The ratio of food-to-microorganism (F/M) on membrane fouling of anaerobic membrane bioreactors treating low-strength wastewater. Desalination 2012; 297:97-103. 